\title{
OBČANSKÉ VEDENÍ OZBROJENÝCH SIL V TEORII A ČESKÉ PRAXI*
}

\section{JAKUB DIENSTBIER}

\begin{abstract}
Civil Governance of the Armed Forces in Theory and Czech Praxis
This paper deals with the issue of the civil and democratic control (civil governance) of the armed forces from the perspective of constitutional law and the state theory. Firstly, the paper explains the importance of studying civil-military relations for the constitutional democracies and tries to find the proper Czech term for the concept of civil and democratic control of the armed forces (i.e. civil governance). In the first part, the paper interprets the sole term of "armed forces" in view of public international law, Czech constitutional and administrative law as well as military theory.

The second part uses Ota Weinberger's theory of normative institutionalism for the theoretical analysis of the civil and democratic control concept. After that, it briefly describes the Huntington's theory of subjective and objective model of civil control and in more detail characterizes the concrete constitutional aspects of the civil and democratic control. The third part shows the deficiencies in the normative and institutional implementation of the civil and democratic control in the Czech Republic and offers some possible changes de constitutione et lege ferenda.
\end{abstract}

Keywords: armed forces; civil governance; civil control; democratic control; civil-military relations

Klíčová slova: ozbrojené síly; občanské vedení; civilní kontrola; demokratické řízení; civilně-vojenské vztahy

DOI: $10.14712 / 23366478.2020 .19$

\section{1. ÚVOD}

„Vláda nynějšiho krále Velké Británie je vládou opakovaných křivd a skutků bezpráví, jednoznačně směrujicich $k$ zavedeni naprostého násili nad těmito státy. Na dưkaz toho, necht' jsou nezaujatému světu predložena fakta. (...) Udržoval u nás, i v dobách míru, zahálející armády bez souhlasu naši legislatury. Přičinil se, aby vojsko bylo nezávislé na moci civilní a jí nadřazeno. "1

Prohlášeni nezávislosti USA z 4. 7. 1776

* Tento článek vznikl v rámci programu Progres Univerzity Karlovy Q18 - Společenské vědy: od víceoborovosti k mezioborovosti. Autor by rád poděkoval J. Kyselovi, V. Derkovi a anonymním recenzentům za cenné připomínky při psaní tohoto textu. Článek na mnoha místech vychází z diplomové práce autora (DIENSTBIER, J. Role ústavnich orgánů při zajištováni bezpečnosti státu. Diplomová práce. Praha: Univerzita Karlova, Právnická fakulta, 2019. Dostupná z: https://dspace.cuni.cz/bitstream/handle $/ 20.500 .11956 / 107555 / 120326692$.pdf?sequence=1\&isAllowed=y), a proto na ni občas pro úplnost odkazuje. Dík za cenné poznámky a připomínky tak patří též vedoucímu diplomové práce J. Kudrnovi. Všechny chyby jdou samozřejmě na vrub autora.

1 Cit. dle KUKLÍK, J. - SELTENREICH, R. Déjiny angloamerického práva. 2. vyd., v nak1. Leges 1. vyd. Praha: Leges, 2011, s. 491-492. 
Povaha každého ústavně-politického režimu ve státě je ve značné míre ovlivněna charakterem vztahu mezi držiteli politické moci a složkami státních ozbrojených sil, resp. jejich špičkami. Tato skutečnost platí po celou dobu existence státnosti; uznávají ji komunističtí vůdci ${ }^{2}$ i teoretikové demokracie ${ }^{3}$ a lze podle ní i určitým způsobem klasifikovat typy států. ${ }^{4}$

Pro ústavní demokracie má řádné nastavení vztahů mezi civilisty a vojáky (civil-military relations) zásadní význam. Proč tomu tak je? Ozbrojené síly totiž představují jednak vykonavatele veřejné moci ultima ratio, jednak klíčového aktéra pro úspěšné provedení státního převratu. ${ }^{5}$ Státy s historickými zkušenostmi se zasahováním vojákủ do ryze politických záležitostí o tomto poznatku není třeba přesvědčovat, nicméně u nás tvrzení o potenciálním nebezpečí ze strany ozbrojených sil může vypadat jako přehnané. Není divu; v našich moderních dějinách o tom skutečně mnoho př́kladů nenalezneme. ${ }^{6}$ Organizace ozbrojených sil je však ze své

2 Srov. Mao Ce Tungovy výroky: „Každý komunista musí vědět jedno - politická moc vychází z hlavně pušky“ nebo „Podle marxistické teorie státu je armáda klíčovým prvkem státní moci. Kdo by chtěl uchopit a udržet státní moc, musí mit silnou armádu." (Překlad autora) Viz Quotations from Mao Tse Tung: 5. War and Peace. Marxists Internet Archive [online]. [cit. 23. 10. 2019]. Dostupné z: https://www .marxists.org/reference/archive/mao/works/red-book/ch05.htm

3 DAHL, R. A. Demokracie a jeji kritici. Překlad Helena Blahoutová. Praha: Victoria Publishing, 1995, s. 222-228.

4 Jsou-li politické orgány nadř́ízené ozbrojeným silám, může jít o stát demokratický či o stát totalitní (v obou jsou civilní politikové nadřízeni vojákům, v každém z nich však poněkud jinak), pokud jsou ozbrojené síly nadřízené politickým orgánům či je nahrazují, pak půjde o vojenskou diktaturu či juntu. Vývojově předcházejícím typem státu byl stát aristokratický, resp. monarchický. Za zvláštní typ je pak třeba označit tzv. kasárenský stát, v němž ozbrojené síly nejsou plně podřízeny politickým orgánům a uplatňují na ně podstatný vliv v souvislosti se svými specifickými zájmy, resp. jsou nadáni plně autonomním postavením (př́íkladem budiž např. Prusko či Německo před první světovou válkou, v posledním půlstoletí je známý zejména z rozvojových zemí). Srov. KŘ Íİ, Z. Armáda v demokracii. Civilní ŕizení a demokratická kontrola armády. Brno: Vojenská akademie, 2001, s. 101-107. Jak autora upozornil J. Kysela, nemusí se autonomní postavení nutně vázat na rozhodování o vlastních záležitostech, nýbrž též na ovládání významné části národního hospodářství (Írán, Venezuela, Egypt). Se silným vlivem vojenských složek a představitelů na výkon státní moci pracuje i J. Reschová při charakteristice nacistického, resp. fašistického typu státu. Srov. RESCHOVÁ, J. Stát. Základní charakteristika. In: RESCHOVÁ, J. - KINDLOVÁ, M. - GRINC, J. - PREUSS, O. - ANTOŠ, M. Státovéda: stát, jednotlivec, konstitucionalismus. Praha: Wolters Kluwer, 2019, s. 28.

5 BANKOWICZ, M. Státni převrat. 1. vyd. v českém jazyce. Praha: Dokořán, 2010, s. 31, 75.

6 Př́íkladem pokusu o státní převrat ze strany vojáků je vzpoura legionářů z roku 1919, kteří chtěli změnit tehdejší ústavně-politický režim na diktaturu v čele s T. G. Masarykem (srov. KLIMEK, A. Velké dějiny zemi Koruny české. Sv. XIII. Praha: Paseka, 2000, s. 72). O státním převratu vážně uvažovali armádní představitelé i v době mnichovské krize roku 1938 (srov. GEBHART, J. - KUKLÍK, J. Velké dějiny zemí Koruny české. Sv. XV.a. Praha: Paseka, 2006, s. 90-92). Ozbrojené síly k silovému řešení politické situace chtěli využít i členové Národní obce fašistické v neúspěšném tzv. Židenickém či Gajdově puči (srov. KLIMEK, A. Velké dějiny zemi Koruny české. Sv. XIV. Praha: Paseka, 2002, s. 208 a násl.); naopak označovat tzv. Homolův puč z roku 1939 za pokus o státní převrat je trochu sporné, nebot' gen. B. Homola jednal na rozkaz oficiálních československých představitelů za účelem ochrany veřejného pořádku a podpory nově jmenované slovenské autonomní vlády. (Srov. GEBHART - KUKLÍK, c. d., s. 162-163). Nicméně Homolovo sdělení v úřední zprávě o tom, že přebírá veškerou správní a soudní moc, překračovalo Ústavní listinu z roku 1920 (uvozenou zákonem č. 121/1920 Sb. z. a n.) po změnách provedených ústavním zákonem č. 299/1938 Sb. z. a n., o autonómii Slovenskej krajiny. Dle M. Mareše a D. Nováka se ale omezení ústavně zaručených občanských práv opíralo o zákon č. 168/1922 Sb. z. a n. (srov. MAREŠ, M. - NOVÁK, D. Ústavni zákon o bezpečnosti České republiky: komentář Praha: Wolters Kluwer, 2019, s. 31). Za upozornění na Gajdův a Homolův puč autor děkuje J. Kyselovi. V tomto přehledu je však ponecháno stranou využití ozbrojených sil komunistickou totalitní mocí na potlačování protestů v roce 
podstaty nedemokratická, ${ }^{7}$ což má důsledky i pro postoje, vzorce chování a rámce myšlení př́slušníků ozbrojených sil; již Montesquieu si všiml, že vojáci volenými reprezentanty lidu a politiky vůbec spíše pohrdají a váží si naopak svých velitelů. Proto pokud jsou v podř́zenosti někoho, kým pohrdají, spíš jej nahradí tím, koho mají v úctě. ${ }^{8}$ Riziko zneužití ozbrojených sil a militarizace státu tak je vždy latentně př́tomno a není možné jej, byt' z teoretického hlediska, vyloučit. ${ }^{9}$

$\mathrm{O}$ čem ale není třeba českou veřejnost přsesvědčovat, je fakt, že se ve prospěch zajištění národní obrany využívají mnohdy ohromné materiální, finanční a lidské zdroje; otázka existence povinné základní vojenské služby nebo jednotlivé zbrojní zakázky jsou totiž témata, která zaznívají i v českém veřejném prostoru. Zajišsění náležitého podílu civilistů na rozhodování právě o otázkách zdrojů je druhým hlavním tématem zkoumáním civilně-vojenských vztahů. ${ }^{10}$ Podíl civilistů na rozhodování navíc může být výhodný i pro obyčejné vojáky v operačním nasazení. ${ }^{11}$

Nicméně ingerence civilistů (politiků) do vojenských záležitostí není a nemůže být bezbřehá. Vojáci, resp. vojenští velitelé jsou odborníky pro vojenská témata, což civilní politici zpravidla nejsou. Podstatný výkon velitelské pravomoci a rozhodování na operační a taktické úrovni ze strany civilních politiků není nejen vhodné, ale často ani možné. Jde tu tak o střet politiky a odbornosti, který v obecné rovině označuje J. Drgonec za jeden z projevů principu dělby moci; ${ }^{12}$ nutno tedy obě roviny vyvažovat. Jak ale zajistit, aby na jednu stranu vojáci respektovali zásadu primátu demokraticky legitimovaných orgánů veřejné moci složených z civilistů, jakožto projevu suverenity lidu v rámci demokratického právního státu, ${ }^{13}$ ale aby na stranu druhou byla politiky respektována odbornost vojenských profesionálů a s tím související autonomní sféra rozhodování?

1953 a 1969 či plánované „vojenské řešeni““ sametové revoluce v roce 1989 (srov. SUK, J. Labyrintem revoluce: aktéři, zápletky a křižovatky jedné politické krize: (od listopadu 1989 do června 1990). Praha: Prostor, 2003, s. 484). Určitým mementem pro české civilně-vojenské vztahy však rozhodně je ovládnutí významných pozic v československé armádě v letech 1945-1948 exponenty Komunistické strany Československa (srov. BÍLEK, J. In: BÍLEK, J. - LÁNÍK, J. - ŠACH, J. Československá armáda v prvním poválečném desetiletí: květen 1945 - květen 1955. Praha: Ministerstvo obrany České republiky, 2006, s. 80 a násl.).

7 VLACHOVÁ, M. Democratic Control of Armed Forces. In: CALLAGHAN, J. - KERNIC, F. (eds.). Armed forces and international security: global trends and issues. Münster: Lit, 2003, s. 199.

8 MONTESQUIEU, Ch. L. de S. O duchu zákonů. Dobrá Voda: Aleš Čeněk, 2003, s. 200-201.

9 STACH, S. - SARVAŠ, Š. Demokratická kontrola bezpečnostní politiky a ozbrojených sil. Mezinárodní vztahy. Praha: Ústav mezinárodních vztahů, 1997, roč. 32, č. 3, s. 38.

10 VLACHOVÁ, c. d., s. 199.

11 Tento možná nečekaný aspekt civilně-vojenských vztahů výstižně popisuje film Války Pentagonu (Pentagon Wars, 1998), natočený podle skutečných knižních vzpomínek penzionovaného armádního důstojníka. Příběh zachycuje, jak během 17 let bylo utraceno více než 14 miliard dolarů na vývoj armádního vozidla, které původně mělo pouze rychle převážet vojáky z místa boje do bezpečí, aby se přeměnilo ve vozidlo připomínající výzbrojí tank, ovšem s pancéřováním, které by neposkytlo osádce ochranu ani před běžnými protitankovými zbraněmi, což se vysocí armádní důstojníci pokoušeli zatajit v obavách před obviněním z mrhání finančních prostředků daňových poplatníků. Díky whistleblowerům a kontrole Kongresu USA však došlo k odhalení této kritické vady a její nápravě, což pravděpodobně v průběhu války v Zálivu zachránilo spoustu amerických životů.

12 Srov. DRGONEC, J. Ústavné právo hmotné. Bratislava: C. H. Beck, 2018, s. 269.

13 Srov. KUDRNA, J. Ústavní zakotvení bezpečnosti České republiky z pohledu uplynulých patnácti let. In: SUCHÁNEK, R. - JIRÁSKOVÁ, V. a kol. Ústava České republiky v praxi: 15 let platnosti základního zákona. Praha: Leges, 2009, s. 329. 
Stávající odpovědí na tuto otázku je koncepce, která je v angloamerickém prostředí známá pod pojmem „civil control of armed forces“ či „democratic control of armed forces“". Při její analýze nás však poněkud zrazuje český jazyk. V angličtině totiž slovo „control“" nezahrnuje pouze činnost dozorčí, dohlížecí, nýbrž i činnost ovládací. Navíc důraz jednou na civilnost (neuniformovanost), jednou na demokratičnost, není př́istupem komplexním. $Z$ tohoto důvodu je doslovný překlad ve tvaru „civilní/demokratická kontrola ozbrojených sil“" v politologické literatuře vnímán jako nepřesný či neúplný a místo něj se užívá slovní spojení „,civilní rízení a demokratická kontrola“. 14

Z právního hlediska je nanejvýš obtížné zvolit správný pojem. Z důvodu jisté jazykové nouze je v tomto článku zvolen termín „občanské vedení ozbrojených sil““. ${ }^{15}$ Pod tím je třeba rozumět jak obecné vytyčení směru činnosti ozbrojených sil, tak i dohlížení (dozor, kontrola stricto sensu), že je směr dodržován. ${ }^{16}$ Zdůraznění občanského charakteru vedení má vyjadřovat, že jde o vedení ozbrojených sil demokraticky legitimovanými civilisty v rámci ústavního systému, založeného na dělbě moci, zákonnosti a ochraně základních práv a svobod.

Civilně-vojenské vztahy obecně, i občanské vedení ozbrojených sil zvláště, byly a jsou předmětem odborného zájmu politologie či sociologie, a to nejen ve světě, nýbrž i u nás. ${ }^{17} \mathrm{Z}$ výše uvedeného vyplývá, že jde o téma, které se podstatně týká i oboru ústavního práva a státovědy. Česká právní věda se však více či méně této problematice vyhýbá, a to i přes existenci ústavní úpravy týkající se ozbrojených sil, která výslovně zmiňuje „civilní kontrolu ozbrojených sil““, jakož i soustavy branného zákonodárství v rovině podústavní. Navíc důležitost občanského vedení ozbrojených sil pro demokratické právní státy podtrhla mezi lety 2006-2008 zpracovaná zpráva Evropské komise pro demokracii prostřednictvím práva Rady Evropy (tzv. Benátská komise). ${ }^{18}$

Téma občanského vedení ozbrojených sil, resp. nedostatky v implementaci tohoto institutu v právním řádu a politické praxi navíc opakovaně zaznívaly v našem veřejném

14 Srov. KŘİŽ, Z. Civilní řizení a demokratická kontrola armády v České republice: peripetie transformace vojensko-civilních vztahů po roce 1989. Brno: Masarykova univerzita v Brně, Mezinárodní politologický ústav, 2004, s. 10-11.

15 J. Kysela autora článku upozornil, že termín „vedeni““ se v tomto kontextu blíží významem pojmu „governance“. Tomu se autor nebrání, ostatně i think-tank DCAF, který se oblasti civilně-vojenských vztahů vůbec a občanskému vedení ozbrojených sil zvláště soustavně věnuje, byl dříve znám jako ,the Geneva Centre for the Democratic Control of Armed Forces“, přičemž v současné době používá název „DCAF - Geneva Centre for Security Sector Governance“. Ve svých publikacích tento think-tank použivá jak „governance“, tak i „democratic civilian control“, byt' „governance“ jako pojem obecnější. Autor tak zdủrazňuje, že pojem „vedení " používá, protože si není vědom výstižnějšího českého slova. V každém př́ípadě je nutno jej vnímat ve smyslu dále uvedeném.

16 Tyto dva dílčí aspekty občanského vedení nemusí být nutně př́ítomny v činnosti všech aktérů, orgánů a institucí, které se na občanském vedení podílí, resp. mohou být př́itomny s různou intenzitou. Přesto, že kupř́íladu u orgánů ombudsmanského typu převažuje dohled, podílí se i tyto orgány na občanském vedení ozbrojených sil.

17 Např. se jedná o HUNTINGTON, S. P. The soldier and the state: the theory and politics of civil-military relations. Cambridge, Mass.: Belknap Press of Harvard University Press, 1985. V českém prostředí pak obě již citované studie $Z$. Kř́že. Uvést je třeba též již zmíněný think-tank DCAF - Geneva Centre for Security Sector Governance.

18 EUROPEAN COMMISSION FOR DEMOCRACY THROUGH LAW (VENICE COMMISSION). Report on the democratic control of the armed forces. Strassbourg: Council of Europe, 2008. Study no. 389/2006. Dostupné z: https://www.venice.coe.int/webforms/documents/default.aspx?pdffile=CDL $-\mathrm{AD}(2008) 004-\mathrm{e}$. 
prostoru, a to nejen v souvislosti s koncem komunistické totalitní moci či vstupem naší republiky do Organizace Severoatlantické smlouvy (NATO); nejde tedy o problematiku fiktivní či pouze akademickou. Motivem pro sepsání tohoto článku je tedy jak absence hlubší ústavněprávní reflexe občanského vedení v naší nauce, tak i existence kontroverzí s tímto tématem spojených.

Avšak které části státního mechanismu se občanské vedení týká? Co jsou ozbrojené síly? Těmto otázkám je věnována část první tohoto článku. Druhá část odpovídá na otázku po obsahu občanského vedení ozbrojených sil a jeho konkrétních aspektech souvisejících s ústavním právem. Třetí část se zaměřuje na slabá místa normativně-institucionální realizace občanského vedení v České republice a přináší návrhy na změny de constitutione et lege ferenda za účelem prohloubení občanského vedení ozbrojených sil u nás.

\section{POJEM OZBROJENÝCH SIL}

Vymezení pojmu ozbrojených sil není jednoduchou záležitostí, nebot' se nám nabízí pohled mezinárodněprávní, ústavní a vojensko-teoretický, príípadně též zákonný (podústavní).

Mezinárodní právo veřejné se při definování pojmu ozbrojených sil soustřed’uje na personální stránku. Ozbrojené síly jsou dle mezinárodního humanitárního práva tradičně tvořeny nekombatanty (pouze př́islušníci vojenské lékařské a duchovní služby) a kombatanty, kteří musí splňovat 4 znaky:

„1) mají v čele velitele odpovédného za své podřizené,

2) nosí pevný rozeznávací znak viditelný na dálku,

3) nosí otevreně zbră̌,

4) dodržuji zákony a obyčeje války."19

Tato tradiční čtyřprvková definice ozbrojených sil, odvozovaná již od roku 1899, ${ }^{20}$ však postupem času prodělala určitý vývoj. Čl. 43 odst. 1 Dodatkového protokolu k Ženevským úmluvám z 12. srpna 1949, který byl přijat 8 . června 1977, o ochraně obětí mezinárodních ozbrojených konfliktů, ${ }^{21}$ definoval ozbrojené síly takto: „Ozbrojené síly strany v konfliktu se skládaji ze všech organizovaných ozbrojených sil, skupin a jednotek, které jsou pod velením osob odpovédných této straně za jednání svých podřizených, a to i v prípadech, $k d y$ strana je zastupována vládou nebo orgánem, který protější strana neuznává. Tyto ozbrojené silly budou podléhat vnitřnímu disciplinárnímu systému, který mezi jiným bude prosazovat dodržováni norem mezinárodního práva aplikovaných v ozbrojených konfliktech. “Ze 4 prvků tak byl zachován pouze prvek první (odpovědné velení) a čtvrtý (dodržování mezinárodního humanitárního práva). ${ }^{22}$

19 FUCHS, J. Mezinárodni humanitární právo. Praha: Ministerstvo obrany - Agentura vojenských informačních služeb, 2007, s. 46.

20 Poprvé ji stanovil čl. 1 Řádu války pozemní, a to ve verzi z roku 1899 i z roku 1907. Srov. FUCHS, c. d., s. 46.

21 Vyhlášen sdělením federálního ministerstva zahraničních věcí č. 168/1991 Sb.

22 Tato definice zahrnuje též guerillové bojovníky, a proto je ze strany některých států (USA, Francie) kritizováno. Srov. FUCHS, c. d., s. 50-51. Za upozornění na problematiku partyzánů autor děkuje J. Kyselovi. 
Nejdále zašla studie o obyčejovém mezinárodním humanitárním právu z roku 2005 (zaštítěná Mezinárodním výborem Červeného kříže), která požaduje pouze podmínku odpovědného velení. ${ }^{23}$ Přese všechno je zřejmé, že mezinárodní právo vyzdvihuje jako hlavní požadavek určitou zvláštní formu organizovanosti ozbrojených sil, ve které v každém př́ípadě funguje odpovědné velení, tj. systém nadřizenosti a podřízenosti spolu s nedělitelnou velitelskou pravomocí a odpovědností, př́ípadně též spolu se specifickým rozlišením a disciplinárním systémem zajištujícím dodržení pravidel mezinárodního práva. Vzhledem $\mathrm{k}$ tomu, že účelem vymezení pojmu ozbrojených sil v mezinárodním humanitárním právu je náležité rozlišení osob, které se legálně mohou účastnit nepřátelství, ${ }^{24}$ je implicitním znakem ozbrojených sil též jejich zvláštní účel, kterým je vedení ozbrojeného konfliktu.

$\mathrm{Z}$ hlediska ústavního ${ }^{25}$ je v rámci ústavního pořádku ČR používán pojem ozbrojených sil v čl. 39 odst. 3, čl. 43 odst. 3, 4 a 5, čl. 63 odst. 1 písm. c) Ústavy České republiky (dále též „Ústava“), ${ }^{26}$ čl. 27 odst. 4 a čl. 44 Listiny základních práv a svobod, ${ }^{27}$ čl. 3 odst. 1, čl. 4 odst. 1 a 2, čl. 11 písm. b) ústavního zákona o bezpečnosti ČR (dále též „ÚZB“"). ${ }^{28}$ Na rozdíl kupř́íkladu od slovenských ústavních předpisů2 ${ }^{29}$ nám součásti ústavního pořádku definici ozbrojených sil neposkytují; je tak třeba k ní dojít výkladem.

Jazykově je možné ozbrojené síly chápat jako ,souhrn vojensky organizovaných a ozbrojených složek“30 či jako „,šechny vojensky organizované a vyzbrojené silly“.31 Opět se objevuje kritérium zvláštní vojenské organizovanosti, jakož i ozbrojenosti. Ozbrojenost sice odlišuje ozbrojené síly od podstatné části státního aparátu, ne však od ozbrojených bezpečnostních sborů. ${ }^{32}$ Nicméně vztahy uvnitr̆ těchto sborů nesplňují kritérium zvláštní vojenské organizovanosti. Toto kritérium vyplývá z účelu ozbrojených sil, resp. smyslu jejich existence, který ústavodárce naznačil v čl. 43 Ústavy a čl. 4 odst. 1 ÚZB a zákonodárce jasně provedl $\mathrm{v} \S 9$ zákona o ozbrojených silách ČR. ${ }^{33}$ Tím je zajištění obrany státu před vnějším napadením, tedy opět vedení ozbrojeného kon-

23 FUCHS, c. d., s. 51.

24 FUCHS, c. d., s. 44-45.

25 Blíže viz DIENSTBIER, Jakub. Role ústavních orgánů při zajištování bezpečnosti státu. Diplomová práce. Praha: Univerzita Karlova, Právnická fakulta, 2019. Dostupná z: https://dspace.cuni.cz/bitstream /handle/20.500.11956/107555/120326692.pdf?sequence=1\&isAllowed=y, s. 21-29.

26 Ústavní zákon č. 1/1993 Sb., Ústava České republiky, ve znění pozdějších předpisů.

27 Vyhlášena pod č. 2/1993 Sb.

28 Ústavní zákon č. 110/1998 Sb., o bezpečnosti České republiky, ve znění ústavního zákona č. 300/2000 $\mathrm{Sb}$.

29 Srov. čl. 1 odst. 6 ústavného zákona č. 227/2002 Z.z., o bezpečnosti štátu v čase vojny, vojnového stavu, výnimočného stavu a núdzového stavu.

30 MEJSTřÍK, V. a kol. Slovnik spisovné češtiny pro školu a veřejnost: s Dodatkem Ministerstva školství, mládeže a tělovýchovy České republiky. 3., opr. vyd. Praha: Academia, 2003, s. 256.

31 HAVRÁNEK, B. a kol. Slovník spisovného jazyka českého. 2., nezměn. vyd. Praha: Academia, 1989, SV. III., s. 631.

32 Úroveň ozbrojenosti navíc odvisí od zdroje ohrožení, proti kterému jsou jednotlivé druhy bezpečnostních složek nasazeny. Policejní síly tak mohou být vyzbrojeny i těžkými zbraněmi a bojovou technikou, pokud čelí vyspělému protivníkovi (gangy, drogové kartely). Přesto i u takto vyzbrojených policejních složek nelze v oblasti institucionálních vztahů nalézt stejně významnou zvláštní vojenskou organizovanost (viz dále). Za poznatek o možné podobnosti výzbroje policejních a ozbrojených sil autor vděčí J. Kudrnovi.

33 Zákon č. 219/1999 Sb., o ozbrojených silách České republiky, ve znění pozdějších předpisů (dále též „ZOS“). 
fliktu, nikoliv ochrana veřejné bezpečnosti a pořádku (tzv. policejních statků). ${ }^{34}$ Vztahy uvnitř ozbrojených sil jsou též zásadně ovlivněny zvláštním požadavkem normativně-institucionální věrnosti, tj. komplexem povinností, vyplývajících pro vojáky z právních předpisů a ze specifických, institucionalizovaných společenských norem uvnitř tohoto státního zařízení. ${ }^{35}$ Lze tedy uzavř́it, že ozbrojené síly znamenají souhrn všech vojáků, tj. všech odvedených osob se služební povinností, (potenciálně) ozbrojených a zavázaných povinností normativně-institucionální věrnosti.

Tento závěr lze podepř́ít i výkladem historickým; svědčí o něm jak důvodová zpráva k ústavnímu zákonu č. 300/2000 Sb., tak i československá právní tradice nebo právní stav ke dni přijetí Ústavy, Listiny základních práv a svobod i ústavního zákona o bezpečnosti ČR, a to za využití výkladového principu zkamenění (Versteinerungstheorie). ${ }^{36}$ Takto dovozenou definici ozbrojených sil však není možné používat při výkladu konkrétních ustanovení ústavního pořádku izolovaně; kupř́íkladu z čl. 43 odst. 3 Ústavy rozhodně nevyplývá, že souhlasu Parlamentu podléhá vyslání ozbrojených sil jako cel$\mathrm{ku}$, nebot' $\mathrm{z}$ teleologického a historického hlediska vyplývá opak. ${ }^{37}$

Prováděcí zákon k čl. 4 odst. 2 ÚZB (zákon o ozbrojených silách ČR) vymezuje ozbrojené síly tak, že se vytváří pro zajištění bezpečnosti ČR, 38 člení na Armádu ČR, Vojenskou kancelář prezidenta republiky a Hradní stráź ${ }^{39}$ a jsou tvořeny vojáky v činné službě. ${ }^{40} \mathrm{~S}$ ohledem na vyšší právní sílu ústavních zákonů a princip samostatnosti ústavních pojmů je nutné podrobit organizační vymezení ozbrojených sil ČR v $\S 3$ odst. 2 ZOS kritice, nebot' mezi tyto tři složky ozbrojených sil nezahrnuje Vojenskou policii či Vojenské zpravodajství, ${ }^{41}$ kde též dominantně působí vojáci v činné službě, uplatňují se zvláštní vztahy vojenské organizovanosti, a které poskytují bezprostřední podporu pro zajištění obrany státu (národní obranu).

Vojenská věda operuje při vysvětlování fenoménu ozbrojených sil specifickým účelem (již zmíněné vedení ozbrojených konfliktů), způsobem organizace jejich př́islušníků a unikátním způsobem jejich doplňování (kromě dobrovolného výkonu vojenské činné služby jde o povinné odvody a mobilizaci). ${ }^{42}$

34 Srov. MATES, P. - ŠKODA, J. - VAVERA, F. Veřejné sbory. Praha: Wolters Kluwer Česká republika, 2011, s. 2-3.

35 Z právního hlediska jde např. o existenci trestných činů, které může spáchat pouze voják jako speciální subjekt trestného činu, či o možnost uložit trest ztráty vojenské hodnosti, pokud to vyžaduje kázeň a pořádek v ozbrojených silách (§ 79 odst. 2 zákona č. 40/2009 Sb., trestní zákoník, ve znění pozdějších předpisů). Z institucionálního hlediska jde o zvláštní esprit de corps vytvářen mj. požadavkem na vojenskou ustrojenost, zdvořilost a povinnost uchování bojových tradic či uctívání bojových zástav a hrobu Neznámého vojína.

36 Blíže viz DIENSTBIER, Role ústavních orgánů, s. 15, 25-27.

37 Za upozornění na nežádoucí důsledky slepého používání takto provedené ústavní definice autor děkuje J. Kyselovi.

$38 \S 3$ odst. 1 ZOS.

$39 \S 3$ odst. 2 ZOS.

$40 \S 3$ odst. 3 ZOS.

41 Případně též Generální štáb Armády ČR či vojenské školy - viz dále.

42 PERNICA, B. Profesionalizace ozbrojených sil: trendy, teorie a zkušenosti. Praha: Ministerstvo obrany České republiky, 2007, s. 20. 
Na základě výše uvedeného můžeme říci, že se jak normy mezinárodního práva veřejného, tak i normy našeho ústavního pořádku a poznatky vojenské teorie shodují na tom, že ozbrojené síly je třeba definovat pomocí následujících znaků:

1. ozbrojené síly představují organizovanou jednotku se zvláštními organizačními vztahy, strukturou a způsobem reprodukce;

2. ozbrojené síly jsou zřizovány za účelem vedení ozbrojených konfliktů, resp. k národní obraně, a k poskytnutí bezprostřední podpory pro naplnění tohoto účelu;

3. ozbrojené síly jsou ozbrojené, tj. pro naplnění svého účelu využívají bojové prostředky, zejména zbraně. ${ }^{43}$

\section{OBČANSKÉ VEDENÍ A JEHO ÚSTAVNĚPRÁVNÍ ASPEKTY}

\subsection{OBECNĚ O OBČANSKÉM VEDENÍ}

Z předchozího výkladu vyplývá, že pro vymezení pojmu ozbrojených sil je třeba 3 výše uvedených znaků; tyto znaky ve svém souhrnu znamenají, že na ozbrojené síly je třeba pohlížet jako na zvláštní státní instituci. ${ }^{44} \mathrm{~V}$ obecné právní teorii pracuje $\mathrm{s}$ institucemi důkladným a přesvědčivým způsobem $\mathrm{O}$. Weinberger, který stál u zrodu teorie normativního institucionalismu (institucionálního pozitivismu, neoinstitucionalismu). Jeho poznatků tak bude využito při objasnění podstaty a obsahu občanského vedení.

Podle O. Weinbergera jsou instituce tvořeny 3 částmi:

1. jádrem praktických informací - tyto informace určují, jakým způsobem „se máme chovat v rámci instituce a jak hodnotit chování z hlediska instituce "; 45 toto ideální jádro je složeno z norem, účelů, hodnot a preferencí, ${ }^{46} \mathrm{~V}$ našem př́padě jde např. o stanovení úkolů ozbrojených sil, kompetencí při jejich ř́zení, pravidel pro jejich nasazení, a to právním předpisem (Ústava, ÚZB, zákon o ozbrojených silách ČR), interní normativní instrukcí (Základní řád ozbrojených sil ČR ${ }^{47}$ ) nebo individuálním aktem řízení (rozkazy nadřizených);

2. osobním substrátem - lidé (jednotlivci i kolektivy) podílející se na životě institucí jako ,nositelé, aktéři a orgány instituci“ ${ }^{48}$ v našem př́padě jde nejen o vojáky v činné službě, ale i o členy ústavních orgánů, jejichž činnost se ozbrojených sil podstatně dotýká (prezident republiky, ministr obrany a další členové vlády...);

43 Shodně GÖTTINGER, V. Činnost a řizení ozbrojených sil v míru jako predmět zkoumání správní vědy. Disertační práce. Brno: Masarykova univerzita, Právnická fakulta, 2012. Dostupné z: https://is.muni. cz/th/iwjr2/, s. 22.

44 Shodně KLÍMA, K. Teorie veřejné moci (vládnutí). 3., přeprac. vyd. Praha: Wolters Kluwer, 2016, s. 220, a KŘÍŽ, Armáda v demokracii, s. 5, 65.

45 WEINBERGER, O. Od brněnské školy k neoinstitucionalismu. In: WEINBERGER, O. - KUBEŠ, V. KOSEK, J. (eds.). Brněnská škola právni teorie: (normativni teorie). V Praze: Karolinum, 2003, s. 406.

46 WEINBERGER, O. Alternativni teorie jednáni: zároveň kritický rozbor praktické filozofie Georga Henrika von Wrighta. Překlad Karel Hlavoň. Praha: Filosofia, 1997, s. 197.

47 Schválený prezidentem republiky dne 21. června 2001, známý též pod zkratkou „Zákl-1“.

48 WEINBERGER, Alternativni teorie jednání, s. 198. 
3. věcným substrátem - tím jsou myšleny ,předměty a produkty, jež jsou vytvářeny a uživány z hlediska svých institucionálně určených funkci“;49 $\mathrm{v}$ našem př́ípadě jde o vojenskou výstroj, výzbroj, techniku a technická zařízení, objekty a prostory, finanční prostředky.

Viděno z těchto pozic, je občanské vedení ozbrojených sil tvořeno dvěma dílčími činnostmi. První činnost spočívá v určení toho, kdo stanovuje jádro praktických informací ozbrojených sil (tj. kdo tvoří normy a určuje účely, hodnoty a preference); tento aspekt jsme při úvodním terminologickém vymezení označili za obecné vytyčení směru činnosti ozbrojených sil. ${ }^{50}$ Druhá činnost spočívá ve sledování a hodnocení souladu jádra praktických informací s osobní a věcnou složkou (substrátem) ozbrojených sil (tj. zda to, co jest, odpovídá tomu, co má býti, resp. tomu, co jest chtěno); tento aspekt je již onou činností dozorovou, dohlížecí, resp. kontrolní stricto sensu ${ }^{51}$ Přidáme-li i hledisko ústavněprávní, pak vzhledem $\mathrm{k}$ principu dělby moci můžeme rozeznávat u obou těchto dílčích činností vnitřní (exekutivní) a vnější (mimoexekutivní) aspekt. ${ }^{52}$

Obě dílč́i činnosti jsou u různých aktérů (orgánů a institucí) vykonávány s různou intenzitou. Na tomto místě je tak třeba se krátce zmínit o Huntingtonově teorii objektivního a subjektivního modelu občanského vedení ozbrojených sil; $; 3 \mathrm{v}$ obou je totiž důraz kladen na odlišné aspekty, a tedy i intenzita u jednotlivých dílčích činností občanského vedení je rozdílná. Objektivní model má spočívat ve vybudování ozbrojených sil jako plně profesionálního, striktně apolitického, od zbytku společnosti spíše odtrženého, a v záležitostech odborně vojenských zcela autonomního sboru, který plní politická zadání bez zaváhání a bez ohledu na to, který politický směr je zrovna u moci. Vedení se v takovém modelu uplatňuje prostřednictvím formálních nástrojů, jakými je zákonodárství, stanovování rozpočtu a posloupnost velení. Subjektivní model považuje ozbrojené síly za souhrn občanů v uniformě; klíčovým aspektem vedení je pro tento model propojení ozbrojených sil se společností a sdílení hodnot ústavně-politického režimu. Pokud vojáci budou považovat stát a společnost za svou, budou vnitřně motivováni $\mathrm{k}$ jejich zachování. $\mathrm{V}$ posledních 30 letech však dochází z mnoha důvodů ${ }^{54} \mathrm{k}$ propojování obou modelů, tedy $\mathrm{k}$ fuzionistickému, ${ }^{55}$ resp. funkčnímu pojetí občanského vedení ozbrojených sil.

49 WEINBERGER, Alternativni teorie jednání, s. 198.

50 Tato dimenze je v politické teorii označována za řízení (ve smyslu určení cílů, vymezení postavení, úkolủ a podmínek). Srov. STACH - SARVAŠ, c. d., s. 38.

51 Tato dimenze je v politické teorii označována za kontrolu (ve smyslu dohledu nad prostředky a postupu naplňování cílů). Srov. STACH - SARVAŠ, c. d., s. 38.

52 Srov. EUROPEAN COMMISSION FOR DEMOCRACY THROUGH LAW (VENICE COMMISSION), c. d., s. 17.

53 Blíže viz KŘíǏ, Civilní rrizení, s. 13-15, či KřÍŽ, Armáda v demokracii, s. 120-127.

54 Např. profesionalizace ozbrojených sil a vysoká komplikovanost moderního vedení boje na straně jedné, společenská integrace vojáků a vojenských rodin a přizpůsobování vzdělávání vojenských profesionálů pro jejich pozdější uplatnění i na civilním trhu práce na straně druhé. Srov. STACH - SARVAŠ, c. d., s. 41-43.

55 STACH - SARVA ̌́, c. d., s. 41. 


\subsection{JEDNOTLIVÉ ASPEKTY OBČANSKÉHO VEDENÍ Z ÚSTAVNĚPRÁVNÍHO POHLEDU}

\subsubsection{STANOVENÍ INSTITUCIONÁLNÍHO JÁDRA}

Tento aspekt občanského vedení obecně spočívá v náležitém uspořádání a fungování struktury orgánů veřejné moci spolu se zabezpečením poslušnosti ozbrojených sil a jejich př́slušníků vůči takové struktuře a jí stanovenému institucionálnímu jádru, a zároveň v zajištění a respektování profesní autonomie vojenských profesionálů v odborně-vojenských tématech. Pro tyto dva prvky je charakteristická již několikrát uvedená nezbytnost vyvážení. ${ }^{56}$ Nebezpečnost převážení vojenské autonomie byla již zmíněna, nebezpečí přináší však i neúměrné zasahování civilistů (politiků a úředníků) do záležitostí čistě vojenských. Jednak se tím (teoreticky kdekoliv, prakticky spíše v zemích s tradičně silným postavením ozbrojených sil) opět zvyšuje riziko státního převratu v důsledku narušení či ohrožení korporativních zájmů vojáků, ${ }^{57}$ jednak v důsledku absence expertních znalostí a zkušeností s vedením boje dochází k neefektivnímu zajištění národní obrany, a to at' už jde o operativně-taktické velení v boji nebo o výběr typů bojové techniky vzhledem $\mathrm{k}$ politicky stanoveným cílům. ${ }^{58}$

Z právního hlediska jde tak hlavně o přijetí takové právní úpravy, která pokrývá všechny relevantní civilně-vojenské vztahy, jednoznačně vymezuje pravomoci a působnosti státních orgánů ve vztahu k ozbrojeným silám (zejména kompetenci vrchního velitele ozbrojených sil a otázku nasazování ozbrojených sil na území vlastního státu i v zahraničí), stanovuje povinnost ozbrojených sil a jejích př́íslušníků se stanovenými normami, účely, hodnotami a preferencemi řídit, jakož i vytvoření odpovídajícího deliktního a sankčního mechanismu pro případ neuposlechnutí.

V rámci stanovování institucionálního jádra praktických informací se však netvoří pouze normy, nýbrž též účely a preference. V našem kontextu jde o vytváření obranné politiky, což př́isluší jak exekutivě (vnitřní občanské vedení), tak i legislativě (vnější občanské vedení). Přitom právě parlamenty realizují při této činnosti svou demokratickou, reprezentační, veřejnou a kontrolní funkci. ${ }^{59}$ Nicméně právě parlamentní role je v této oblasti, jakož i v oblasti sledování a hodnocení souladu institucionálního jádra se stavem osobní a věcné složky ozbrojených sil (viz dále), podstatně limitována v důsledku čím dál tím komplexnější povahy bezpečnostních záležitostí, nedostatku času, a hlavně nedostatku expertních znalostí. To vše volené zastupitele lidu činí spíše více než méně

56 VLACHOVÁ, c. d., s. 200.

57 BANKOWICZ, c. d., s. 69.

58 Podle některých vojenských odborníků by př́kladem byla válka ve Vietnamu, při níž americký prezident L. B. Johnson a jeho ministr obrany R. McNamara osobně určovali konkrétní cíle leteckého bombardování a vojenských operací, dislokaci vojenských jednotek i jejich materiální a personální potřeby. Toto zasahování, vyvolané obavou z eskalace konfliktu případným přímým zapojením Č́nské lidové republiky po korejském vzoru, způsobilo poměrně velkou nechut' vysokých vojenských velitelů. Srov. TRUSK, D. F. Demokracie a obrana: Občanské řizení ozbrojených sil ve Spojených státech. Vídeň: Informační agentura Spojených států amerických, 1993, s. 38-40. Ti posléze zastávali názor, že právě „neodborné“ politické zasahování mělo za následek americkou porážku a pro budoucí rozsáhlejší konflikt (válka v Zálivu) si vynutili široký autonomní prostor pro taktické rozhodování.

59 Srov. výčet parlamentních funkcí v SCHLIESKY, U. In: BADDENHAUSEN, H. - BLUM, P. - BROCKER, L. et al. Parlamentsrecht: Praxishandbuch. Baden-Baden: Nomos, 2016, s. 220 a násl., 243 a násl. 
závislé na informacích od zástupců výkonné moci, resp. od vojáků samých. ${ }^{60}$ Má-li býti tento informační deficit zmenšen, pak je nutné tomu přizpůsobit jednak parlamentní strukturu (obligatorní existence zvláštních orgánů parlamentu či jeho komor), jednak ji vybavit specializovaným personálem (v rámci pomocných úřadů parlamentu či pomocí speciálního orgánu). ${ }^{61}$

Významnou otázkou je též obsazování vrcholného politického postu na úseku obrany státu (v prezidentských režimech hlava státu a ministr/sekretáŕ obrany, v parlamentních zpravidla pouze ministr obrany) bývalými vojáky z povolání, což nemusí být př́liš vhodné $\mathrm{z}$ důvodu jejich jiného předporozumění a potenciálního vnitřního konfliktu rolí. ${ }^{62} \mathrm{Na}$ druhou stranu je třeba zvažovat i funkce, které dotyčná osoba v minulosti v ozbrojených silách zastávala. Pokud sloužila spíše v nebojových útvarech či funkcích, jako jsou pomocné úřady hlav států nebo posty vojenského přidělence v rámci diplomatického zastoupení státu $\mathrm{v}$ zahraničí, měla by být pro princip primátu politiky vnímavější. Koneckonců byl to právě americký prezident D. Eisenhower, většinu života strávivší jako voják z povolání, který upozornil americkou veřejnost na nebezpečí vojensko-průmyslového komplexu (viz dále). Plošné vyloučení bývalých vojenských profesionálů z možnosti zastávat veřejné funkce tak není vhodné a bude třeba detailně zkoumat minulost a osobní profil každého uchazeče jednotlivě. Řešení tak zůstává pouze ve sféré politické kultury. Nezbytné je však právní zakotvení neslučitelnosti funkcí vedoucích a vedených (resp. též dozorujících a dozorovaných); připuštění kumulace funkcí by zjevně popřelo východisko občanského vedení spočívající ve shora zmíněném primátu demokraticky legitimovaných civilistů před vojenskými osobami. Na ústavní úrovni takové ustanovení znají kupř́íkladu v USA, kde dle čl. I oddílu 6 in fine tamní ústavy nesmí býti členem Kongresu žádná osoba, která vykonává jakýkoliv federální úřad, což se dle doktrinálního výkladu vztahuje i na př́slušníky ozbrojených sil USA. ${ }^{63}$ Možným, a pro občanské vedení prospěšným, doplněním neslučitelnosti funkcí může být i stanovení karenční doby (cooling-off period) mezi ukončením služebního poměru vojáka z povolání a nastoupením do výše zmíněných vrcholných politických postů; snížilo by se tak riziko čistě formálního dodržení požadavku neslučitelnosti funkcí. ${ }^{64}$

${ }^{60}$ EUROPEAN COMMISSION FOR DEMOCRACY THROUGH LAW (VENICE COMMISSION), c. d., s. 14.

61 EUROPEAN COMMISSION FOR DEMOCRACY THROUGH LAW (VENICE COMMISSION), c. d., s. 36.

62 U člověka, který téměř celý svůj život (od 18-19 let a u absolventů vojenských gymnázií již od 15 let!) prožil v uniformě a své životní postoje, návyky a vzorce chování získával pod silným vlivem instituce tradičně označované sociology za „totálni“", spočívající ve vojenské disciplinovanosti a oddanosti, existuje riziko, že bude k excesủm ozbrojených sil shovívavější, resp. že nebude k narušování primátu civilistů a porušování (byt' i potenciálnímu) politiky stanovených norem, účelů, hodnot a preferencí vnímavější. Na odlišnost vojenské a civilní mentality upozorňuje i J. Kysela, odkazuje na klasiky ústavní teorie B. Constanta a K. Loewensteina. Srov. KYSELA, J. Ústava mezi právem a politikou: úvod do ústavni teorie. Praha: Leges, 2014, s. 164.

${ }^{63}$ Srov. WALKER, J. FBI Independence as a Threat to Civil Liberties: An Analogy to Civilian Control of the Military. The George Washington Law Review, 2018, vol. 86, no. 4, s. 1018-1019.

${ }^{64} \mathrm{Za}$ tento podnět autor děkuje anonymnímu recenzentovi. 
Pro tento aspekt vedení, zejména pokud jde o vztah k hodnotám, je rozhodující, zda se politické orgány rozhodly preferovat spíše objektivní či spíše subjektivní model podle S. Huntingtona. Pokud je preferován objektivní model, pak se dohled vztahuje pouze na dodržování právního řádu při činnosti ozbrojených sil, resp. na to, zda vojáci ctí hodnotu apolitičnosti a profesionalismu. Pokud je však preferován spíše model subjektivní, bude dohlížející orgány kromě dodržování legality zajímat, zda jsou vojáky sdíleny hodnoty (principy, základní zásady) ústavního řádu, tj. v př́ípadě ústavních demokracií princip ochrany lidských práv, demokracie, právního státu a dělby moci.

Již zmíněná charakteristika ozbrojených sil jako z podstaty nedemokratické a totální instituce však př́iliš neodpovídá prostředí, kde bychom hledali demokraticky smýšlející aktivní občany. ${ }^{65}$ Problémem souvisejícím s odmítáním hodnot ústavní demokracie je též působení politických extremistů v ozbrojených silách, nebot' ty jsou, jak ukazují zkušenosti z Německa, pro extremisty přitažlivé. ${ }^{66}$ Občanské vedení (vnitřní i vnější) se $\mathrm{v}$ této oblasti zaměřuje na dohled nad systémem odhalování zájemců o službu v ozbrojených silách z řad extremistů, jakož i na monitorování situace v ozbrojených silách. Další podstatnou oblastí je sledování atmosféry, která $\mathrm{v}$ ozbrojených silách panuje, a to s ohledem na možnou šikanu, tzv. zupáctví a porušování lidských práv a svobod vojáků. Je třeba se soustavně přesvědčovat o tom, zda jsou stanovené normy vojáky dodržovány a určené hodnoty skutečně vyznávány, a vytvořit pro tuto dohlížecí činnost náležité institucionální zázemí. Další projev tohoto aspektu se týká souladu jednání př́ílušníků ozbrojených sil s normami mezinárodního práva humanitárního a lidskoprávními závazky státu, jakož i s hodnotami, které tyto normy a závazky chrání.

Normy mezinárodního humanitárního práva požadují, aby státy podnikly za účelem jejich implementace nejrůznější opatření, at' už preventivního, průběžného nebo následného charakteru. ${ }^{67} \mathrm{~S}$ občanským vedením souvisí zejména povinnost šíření znalosti mezinárodního humanitárního práva, trestního zákonodárství a koordinace aktivit státních orgánů a dalších subjektů. Celá oblast implementačních opatření průběžného charakteru má v podstatě rrídící povahu, ačkoliv se mezinárodní právo zaměřuje na řízení prostřednictvím vojenských velitelů a na mezinárodní dohled (ochranné mocnosti

65 Ve Spojených státech má právě tato silná nedůvěra veřejnosti k ozbrojeným silám a odpor k vojenskému zasahování do civilních záležitostí podle Nejvyššího soudu USA „silné kořeny v naší národní historii“ (srov. rozhodnutí Laird v. Tatum, 408 U.S. 1 [1972]). Nicméně se zdá, že i tato ostražitost se pomalu vytrácí, nebot', jak autora upozornil J. Kysela, již F. Zakaria označil ozbrojené síly USA za instituci, která požívá značné důvěry ze strany americké veřejnosti (srov. ZAKARIA, F. Budoucnost svobody. Praha: Academia, 2004, s. 304). Tuto skutečnost potvrzují E. A. Posner a A. Vermeule, avšak na druhou stranu zdůrazňují, že americká kultura není militaristická a historicky krom 3 osob žádný vysoký vojenský velitel neuspěl jako vrcholný politik, tj. ve funkci prezidenta (srov. POSNER, E. A. a VERMEULE, A. The executive unbound: after the Madisonian republic. New York: Oxford University Press, 2013, s. 186). Čerstvé výzkumy Y. Mounka ale uvádějí, že v současné době si jeden Američan z šesti myslí, že „armádni klika představuje dobrý systém vládnuti" (srov. MOUNK, Y. Lid versus demokracie: proč je naše svoboda v ohroženi a jak ji zachránit. Praha: Prostor, 2019, s. 13).

66 V Německu je zhruba pět set vojáků podezřelých z náklonnosti k pravicovému extremismu - Romea.cz [online]. [cit. 29. 12. 2019]. Dostupné z: http://www.romea.cz/cz/zpravodajstvi/zahranicni/v-nemecku -je-zhruba-pet-set-vojaku-podezrelych-z-naklonnosti-k-pravicovemu-extremismu.

67 FUCHS, c. d., s. 187 a násl. 
a Mezinárodní výbor Červeného kř́že); vedení (resp. konkrétně dohled) prostřednictvím jiných vnitrostátních orgánů není obligatorní. ${ }^{68}$ Občanské vedení však spočívá i v povinnosti stíhat všechna porušení mezinárodního humanitárního práva, přičemž o závažná porušení půjde např. v př́ípadě usmrcení nekombatanta nebo mučení. ${ }^{69}$

Takové povinnosti jsou v právu lidských práv označovány za pozitivní závazky, resp. institucionální záruky. ${ }^{70}$ Judikatura Evropského soudu pro lidská práva, vykládající ustanovení evropské Úmluvy o ochraně lidských práv a základních svobod (dále též „Úmluva“) ${ }^{71}$ týkající se práva na život a zákazu mučení, a na ni navazující judikatura českého Ústavního soudu, vyžadují (obdobně jako mezinárodní humanitární právo) existenci zákonů trestajících porušení těchto práv, jakož i odpovídajícího soudního a administrativního aparátu. Tento aparát musí provést tzv. účinné vyšetřování $\mathrm{v}$ př́padě porušení výše zmíněných práv - vyšetřování je účinné, pokud je podniknuto nezávislým a nestranným orgánem, rychle a efektivně, pod veřejnou kontrolou a započato z vlastní iniciativy.72 Podle Evropského soudu pro lidská práva se působnost Úmluvy vztahuje i na osoby, které se nalézají v moci vojáků některé z Vysokých smluvních stran (tedy např. i př́slušníků ozbrojených sil České republiky). ${ }^{73}$ Převažující názor doktríny pak charakterizuje vztah mezinárodního humanitárního práva a práva lidských práv jako vztah komplementární, tedy nikoliv navzájem se vylučující, přičemž i s ohledem na opakovaná rozhodnutí Mezinárodního soudního dvora je třeba oba právní subsystémy aplikovat společně; rozhodnutí o použití konkrétní normy jako lex specialis odvisí od konkrétní situace a okolností. ${ }^{74}$ Evropský soud pro lidská práva navíc zastává postoj, že i v době a na místě probíhajícího ozbrojeného konfliktu je třeba aplikovat Úmluvu

68 FUCHS, c. d., s. 198-199.

69 FUCHS, c. d., s. 205 a násl.

70 BARTOŇ, M. In: BARTOŇ, M. a kol. Základní práva. Praha: Leges, 2016, s. 53-54.

71 Č. 209/1992 Sb.

72 KRATOCHVÍL, J. In: KMEC, J. a kol. Evropská úmluva o lidských právech: komentár. Praha: C. H. Beck, 2012, s. 369. Podle P. Molka byl požadavek zahájení vyšetřování z vlastní iniciativy přidán Ústavním soudem ČR v usnesení sp. zn. I. ÚS 2886/13 a Evropský soud pro lidská práva jej nevyžaduje (srov. MOLEK, P. Základní práva. Svazek první, Di̊stojnost. Praha: Wolters Kluwer, 2017, s. 63-64). Je pravdou, že ani zmíněný komentár̆ $\mathrm{k}$ Úmluvě tuto povinnost nezmiňuje, nicméně v rozhodnutí Evropského soudu pro lidská práva ve věci Isayeva, Yusupova a Bazayeva proti Rusku (rozsudek ze dne 24. 2. 2005, č. 57947/00, § 209), na který zmíněné usnesení Ústavního soudu odkazuje, je výslovně uvedeno následující: „However, whatever mode is employed, the authorities must act of their own motion once the matter has come to their attention."

${ }^{73}$ KRATOCHVÍL In: KMEC a kol., c. d., s. 41. Jedná se o tzv. test specifické kontroly. Jak ve svém článku uvedla V. Bílková, v době jeho vytváŕení nebylo zřejmé, zda se vztahuje pouze na občany Vysokých smluvních stran Úmluvy a zároveň, zda se pro určení jurisdikce Vysokých smluvních stran využije teze o „evropském veřejném pořádku“, která by způsobila, že ke specifické kontrole může dojít jen v rámci Evropy. Srov. BÍLKOVÁ, V. Ochrana lidských práv za ozbrojeného konfliktu? Př́ístup Evropského soudu pro lidská práva. Právnik. Praha: Ústav státu a práva AV ČR, v. v. i., 2008, vol. 147, č. 1, s. 29. Nicméně po sérii případů souvisejících s vojenským angažmá Velké Británie ve válce v Iráku je již zřejmé, že se specifická kontrola vztahuje na kohokoliv a kdekoliv. Srov. BÍLKOVÁ, V. Extrateritoriální aplikace lidských práv - Pohled z Evropy a z Ameriky. In: ŠTURMA, P. a kol. Mezinárodní ochrana lidských práv: regionální a tematická diferenciace. Praha: Univerzita Karlova, Právnická fakulta a Eva Rozkotová - IFEC, 2011, s. 14, 20.

74 MRÁZ, J. Mezinárodní humanitární právo a ochrana lidských práv za ozbrojených konfliktů. In: ŠTURMA, P. - FAIX, M. (eds.). Lidskoprávní dimenze mezinárodního práva. Praha: Univerzita Karlova, Právnická fakulta Eva Rozkotová, 2014, s. 216, 220. 
samostatně bez ohledu na mezinárodní humanitární právo, pokud zároveň nedojde $\mathrm{k}$ derogaci dle čl. 15 Úmluvy. ${ }^{75}$

Pro úplnost je třeba zmínit i otázku soudní kontroly, která je akcentována i Benátskou komisí. ${ }^{76}$ Role soudů při výkonu občanského vedení je však pravděpodobně nejproblematičtějším místem z hlediska ústavního práva, nebot' ústavní teorie i praxe mnoha demokratických právních států otázky o ozbrojených silách označují za politické a působnost soudní moci omezují či prrímo vylučují mj. s odkazem na princip dělby moci. ${ }^{77}$ Za minimální základ činnosti soudů při výkonu občanského vedení v jeho dozorovém aspektu je tak třeba považovat existenci civilního soudního přezkumu v otázkách právního poměru a právních deliktů př́slušníků ozbrojených sil, byt' by k němu mělo dojít až na nejvyšších stupních soudní soustavy (soudy nejvyšší či ústavní). Poskytování ochrany subjektivním právům, zejména pak právům základním je totiž neodmyslitelnou součástí soudního výkonu spravedlnosti v demokratických právních státech.

\subsubsection{SOULAD ÚČELŮ A PREFERENCÍ SE STAVEM VĚCNÉHO SUBSTRÁTU}

Již bylo řečeno, že věcný substrát institucí zahrnuje jejich materiální složku; podstatou tohoto aspektu občanského vedení je sledování, zda je materiální složka dostatečná a je využívána efektivně, tj. zda je schopna sloužit $\mathrm{k}$ naplnění stanovených cílů (účelů a preferencí). V oblasti ozbrojených sil jde o „docílení maximálně možné obranné schopnosti při minimálních výdajích ${ }^{\text {“ }}{ }^{78}$ Více než kde jinde jde právě v tomto aspektu občanského vedení o kontinuální proces, ${ }^{79}$ nebot' jde o náročné vyvažování různých, často protichůdných tendencí a zájmů. V ozbrojených silách jsou totiž latentně př́itomny sklony vyžadovat stále větší množství zdrojů, ${ }^{80}$ pro jejichž ospravedlnění u zbytku společnosti mají vojenské špičky možnost ovlivňovat veřejné mínění pomocí nejrůznějších PR nástrojů日1 a využívat při tom svého monopolu na expertní znalos-

75 ŠTURMA, P. In: ONDŘEJ, J. a kol. Mezinárodní humanitární právo. Praha: C. H. Beck, 2010, s. 36. Takový je ostatně názor i Výboru pro lidská práva při aplikaci Mezinárodního paktu o občanských a politických právech (č. 120/1976 Sb.); srov. BÍLKOVÁ, V. Boj proti terorismu z pohledu ochrany lidských práv. Plzeň: Vydavatelství a nakladatelství Aleš Čeněk, 2014, s. 190.

76 Srov. EUROPEAN COMMISSION FOR DEMOCRACY THROUGH LAW (VENICE COMMISSION), c. d., s. 60 a násl.

77 Pro stručné nastínění problematiky viz DIENSTBIER, J. Omezení soudního přezkumu v ústavním právu. In: ANTOŠ, M. - WINTR, J. (eds.). Poměrováni základních práv. Praha: Univerzita Karlova, Právnická fakulta, 2018.

${ }_{78}$ KŘÍŽ, Armáda v demokracii, s. 116.

79 VLACHOVÁ, c. d., s. 204.

${ }^{80}$ KŘíž, Armáda v demokracii, s. 84.

81 KŘ́ĺ̌́, Civilní řizení, s. 96 . V poslední době je naše Armáda poměrně aktivní právě v souvislosti se zbrojními zakázkami (novým bojovým vozidlem pěchoty a bitevními vrtulníky), kdy na sociálních sítích opakovaně vysvětluje, proč tu či onu vojenskou techniku potřebuje a jaké jsou její výhody. Kampaň pak zakončují shrnující vystoupení armádních špiček, které jsou předem avizovány za pomocí slov „naléhavé“, „důležité sdělení“ a „,neodkladná záležitost“ (viz https://twitter.com /ArmadaTweetuje/status/1138087082780450816?s=20 či https://twitter.com/ArmadaTweetuje /status/1178583513131560960?s=20). Tento článek nemá však za cíl podrobit tuto novou komunikační strategii zásadní kritice, nýbrž spiše na tento specifický projev vojenské činnosti upozornit, aby s ním bylo při výkonu občanského vedení počítáno. Možnost ovlivňování veřejného mínění pomocí nástrojů sebepropagace ozbrojených sil se ostatně netýká pouze věcného (rozpočtového) aspektu občanského vedení, nýbrž i všech ostatních. Názorným př́íkladem budiž i v České republice oblíbený seriál Hvězdná 
ti, který „latentně narušuje primát politiky“ “. $82 \mathrm{Na}$ druhou stranu nejsou v době (byt' zdánlivého) klidu a míru armádní výdaje u veřejnosti př́liš populární. ${ }^{83}$ Do toho všeho vstupuje navíc i určitá nedůvěra veřejnosti v souvislosti s nejrůznějšími, vždy hojně medializovanými kauzami ${ }^{84}$ nebo, zejména ve Spojených státech od 60. let 20. století často diskutované, potenciální nebezpečí propojení (stávajících nebo bývalých) politických, vojenských a podnikatelských špiček do tzv. vojensko-průmyslového komplexu. ${ }^{85}$

Pro řádné vyvážení těchto zájmů a tendencí je nezbytné vnější občanské vedení, spočívající v účasti parlamentu, at' už při schvalování významných zbrojních projektů, nebo v rámci každoročního schvalování státního rozpočtu a státního závěrečného účtu. Tato parlamentní dohlížecí role v rámci rozpočtové pravomoci je považována za klíčovou např. ve Spolkové republice Německo, kde podle zavedené parlamentní praxe nejsou realizovány významné zbrojní projekty či projekty převyšující 250 milionů EUR bez souhlasu výboru pro obranu Spolkového sněmu. ${ }^{86}$ Koneckonců už sám německý ústavodárce, veden snahou předejít zastřenému budování ozbrojených sil v době výmarského Německa, ${ }^{87}$ považoval sledování souladu věcné složky ozbrojených sil se stanoveným politickým zadáním (účely a preferencemi) za natolik klíčovou složku občanského vedení ozbrojených sil, že její hlavní nástroje upravil v Základním zákoně SRN; 88 mezi ně patř́ povinnost vykázat ve spolkovém rozpočtu velikost a strukturu ozbrojených sil, přičemž obligatorně zřizovaný výbor pro obranu Spolkového sněmu požívá postavení výboru vyšetřovacího. ${ }^{89}$ Pro dodání alternativních informací o stavu a činnosti ozbrojených sil byla čl. 45b GG zrŕzena funkce branného zmocněnce Spolkového sněmu (Wehrbeauftragter des Bundestages), jemuž př́sluší působit při ochraně základních práv v ozbrojených silách i jako pomocný orgán Spolkového sněmu př́i zajišstování parlamentní kontroly. Byl to právě branný zmocněnec, který po ostré kritice

brána (Stargate SG-1, 1997-2007), který vznikl ve spolupráci s americkými ozbrojenými silami. Tento seriál na několika místech líčí politiky (členy Kongresu USA) jako zkorumpované, občanské vedení jimi vykonávané označuje za překážku při obraně země, civilní bezpečnostní složky (tajná služba NID je zřejmou narážkou na CIA) pak seriál vykresluje tak, že jdou za vlastním zájmem bez ohledu na oběti. Sdělením seriálu „mezi řádky“ tak je, že je třeba věřit ozbrojeným silám, které to s naší ochranou myslí dobře a jsou dostatečně kontrolovány vnitřními mechanismy se spravedlivým prezidentem jako vrchním velitelem v čele.

82 KŘÍŽ, Armáda v demokracii, s. 111.

83 Autor rozhodně nechce tvrdit, že se v takovém stavu Evropa zrovna nachází.

84 Př́ikladem může být úsměvný belgický problém s modernizací obrněných vozidel. Viz Belgie zmodernizovala pandury, ted’ se do nich většina vojáků nevejde. iDNES.cz [online]. [cit. 29. 12. 2019]. Dostupné z: https://www.idnes.cz/zpravy/zahranicni/pandur-belgie-vojaci-vyska-modernizace.A191220_061511 _zahranicni_aug. Vnímání korupce se zabýval mezinárodní výzkum v letech 2006-2007, ve kterém se státy NATO umístily kolem průměru, tj. poměrně solidně, ovšem s výjimkou Turecka. Srov. SCOTT, D. - PYMAN, M. Public Perceptions of Corruption in the Military in Europe and the Rest of the World. European Security, 2008, vol. 17, no. 4, s. 500.

85 Pro stručné vysvětlení tohoto pojmu viz LÁNÍK, J. Jak se zrodil termín „,vojensko-průmyslový komplex“ [online]. [cit. 14. 11. 2019]. Dostupné z: http://www.vhu.cz/jak-se-zrodil-termin-vojensko-prumyslovy -komplex/.

86 RYJÁČEK, J. Spolkový sněm a nasazeni ozbrojených sil v zahraničí. Praha: Karolinum, 2012, s. 218, 220.

87 RYJÁČEK, c. d., s. 58-59.

88 Grundgesetz für die Bundesrepublik Deutschland, dále též „GG“.

89 Čl. 87a odst. 1 a čl. 45 a odst. 1,2 GG. 
stavu vojenských základen zapříčinil zahájení rozsáhlého modernizačního programu německého Bundeswehru. ${ }^{90}$

Není možné též opomenout podstatnou roli účetních dvorů či státních auditorských orgánů, poskytujících pro parlamenty i výkonnou moc důležitou zpětnou vazbu stran dodržování účetních standardů či již zmíněné hospodárnosti př̌i využívání svěřeného majetku a prostředků. ${ }^{91}$ Možnou otázkou na tomto místě může být, zda se členové a pracovníci těchto institucí vyznají i ve specifických branných záležitostech.

\section{OBČANSKÉ VEDENÍ V ČR - NEDOSTATKY A NÁVRHY NA ZMĚNU}

\subsection{STANOVOVÁNÍ INSTITUCIONÁLNÍHO JÁDRA V ČR}

Ústavní zákon o bezpečnosti ČR uložil Parlamentu přijmout takovou zákonnou úpravu, která stanoví rozsah branné povinnosti, úkoly, organizaci, prípravu a doplňování ozbrojených sil, jakož i právní poměry jejích př́slušníků, a to tak, aby byla zabezpečena „civilní kontrola ozbrojených sil““.92 Úvodním problémem je již samotné použití pojmu „civilní kontrola“, který neobsahuje stricto sensu ani první dílčí činnost občanského vedení, tj. obecné vymezení směru činnosti, ani důraz na jiné hodnoty než je pouhá civilnost (neuniformovanost). $Z$ hlediska politologického by tak ústavodárce mohl být pokárán za terminologickou nepřesnost. P. Uhl se tuto tvrzenou nepřesnost snaží zhojit extenzivním výkladem pojmu „kontrola“ tak, že zahrnuje jak činnost kontrolní, tak i kontrolu nad činností. ${ }^{93} \mathrm{~J}$. Kysela ovšem autora upozornil i na interpretační přístup, podle kterého si ústavodárce mohl skutečně přát pouze výkon kontroly stricto sensu, tj. dozoru (dohledu). Tato dílčí složka občanského vedení však nedává dost dobrý smysl bez druhé dílčí složky, kterou je již zmíněné obecné vytyčení směru činnosti ozbrojených sil, protože pokud by si ozbrojené síly samy určovaly brannou politiku a samy rozhodovaly o svém nasazení, měl by takový vnější dohled povahu pouhé nezávazné zpětné vazby. Navíc by se již nejednalo o demokratický právní stát, nýbrž o stát kasárenský nebo př́mo o juntu. Kompromisní interpretace může vypadat tak, že ústavodárce chtěl tímto článkem zdůraznit význam dohlížecí činnosti, nebot' obecné vymezení směru činnosti považuje za samozřejmě obsažené v pojmu demokratického právního státu.

Skutečným slabým místem tohoto ústavního ustanovení je nestanovení občanského vedení jako obecného principu civilně-vojenských vztahů, nýbrž pouze jako směrnice pro zákonodárce při úpravě výše zmíněných oblastí, aniž by bylo naznačeno, jakým

90 RYJÁČEK, c. d., s. 221.

91 Srov. EUROPEAN COMMISSION FOR DEMOCRACY THROUGH LAW (VENICE COMMISSION), c. d., s. 66-67.

92 Čl. 4 odst. 2 ÚZB.

93 Srov. UHL, P. In: RYCHETSKÝ, P. a kol. Ústava České republiky; Ústavní zákon o bezpečnosti České republiky: komentár. Praha: Wolters Kluwer, 2015, s. 1148. 
způsobem tak má učinit. ${ }^{94}$ Jazykově vzato tak požadavek „civilní kontroly“ dopadá pouze na vztah k právním předpisům ve stanovených oblastech, a nikoliv na všechny činnosti týkající se ozbrojených sil. Ačkoliv je zřejmé, že požadavek občanského vedení má širší dosah a lze jej systematickým výkladem dovodit již z čl. 1 odst. 1, čl. 2 odst. 1 a čl. 9 odst. 2 a 3 Ústavy, ${ }^{95}$ neposkytuje pevnou ústavněprávní oporu pro jednu z dlouhodobě diskutovaných kontroverzí spojených s občanským vedením u nás, kterou je opakované jmenování bývalých vojenských důstojníků do funkce ministra obrany ${ }^{96}$ nebo do funkcí hlavních tvůrců zásadních reformních kroků v oblasti výstavby ozbrojených sil u nás. ${ }^{97}$

De constitutione lata není stanovena překážka pro jmenování bývalého vojáka členem vlády. Navíc prezident republiky, pokud jej vnímáme sice jako prvek vyvážení $\mathrm{v}$ systému dělby moci, avšak pořád $\mathrm{v}$ rámci modifikovaného parlamentarismu, by nemohl odmítnout jmenování navrhovaného ministra pouze pro jeho bývalou vojenskou hodnost a funkci. Rozdíl by nastal pouze, pokud by bývalý voják představoval konkrétní bezpečnostní hrozbu; v takovém případě by odmítnutí jmenování této osoby členem vlády bylo splněním ústavní povinnosti podílet se na zajištování bezpečnosti republiky dle čl. 3 odst. 2 ÚZB, nikoliv svévolným kladením podmínek bez opory v ústavní normě.

Je však třeba poznamenat, že požaduje-li čl. 4 odst. 2 ÚZB, aby organizace a právní poměry př́slušníků ozbrojených sil zabezpečovaly „civilní kontrolu“, je nezbytné stanovení neslučitelnosti funkcí mezi aktivními př́slušníky ozbrojených sil a členy institucí vykonávajících občanské vedení. Zákonodárce stanovil, že přerušení služebního poměru vojáka z povolání nastává „po dobu výkonu funkce dle zvláštního předpisu“ .98 Jak komentářová literatura, ${ }^{99}$ tak i nenormativní poznámka pod čarou odkazují na provedení v branném zákoně, ${ }^{100}$ ve kterém se dozvíme, kdo se po dobu výkonu funkce $\mathrm{k}$ vojenské činné službě nepovolává nebo komu se vojenská činná služba přerušíi. ${ }^{101}$ Ani v jednom z těchto dvou zákonů, a ani v zákoně o střetu zájmů či v zákoně o volbě prezidenta republiky nenajdeme výslovně stanovenou neslučitelnost funkce prezidenta republiky s výkonem vojenské činné služby, tedy zejména se služebním poměrem vojáka z povolání. Jde tedy o jednoznačnou mezeru v zákoně de lege ferenda. Pro

94 Že ústavní zákon nestanovuje způsob „civilní kontroly“ si všímá V. Pavlíček. Srov. PAVLÍČEK, V. a kol. Ústava a ústavní rád České republiky: komentár. 2. díl, Práva a svobody. 2., dopl. a podstatně rožs. vyd. - aktualiz. dotisk [i.e. 3. vyd.]. Praha: Linde, 2002, s. 385.

${ }^{95}$ Shodně KYSELA, J. In: KLÍMA, K. a kol. Komentář k Ústavě a Listině. 2., rozš. vyd. Plzeň: Vydavatelství a nakladatelství Aleš Čeněk, 2009, s. 872, a M. Mareš s D. Novákem In: MAREŠ - NOVÁK, c. d., s. 148.

${ }^{96}$ Od 1. 1.1993 šlo celkem o 3 ministry obrany, a to o J. Tvrdíka (2001-2003), M. Kostelku (2003-2004) a V. Picka (2013-2014).

${ }^{97}$ Jde zejména o J. Škopka a J. Váňu, kteří se na přelomu století významně podíleli na zpracování reformy Armády České republiky, a to prvně jmenovaný v pozici vládního zmocněnce pro reformu, druhý pak jako náměstek ministra obrany pro reformu. Blíže viz Kř́í̌, Civilní řizení, s. 89. Problémem zde je, podobně jako když např. návrhy kodexů procesního práva zpracovávají pouze soudci, nevyváženost profesních zájmů a pohledů.

98 § 11 odst. 1 písm. a) zákona č. 221/1999 Sb., o vojácích z povolání, ve znění pozdějších předpisů.

${ }^{99}$ Srov. ZBOŘIL, T. - KUBÍNYI, L. In: SKORUŠ́A, L. a kol. Zákon o vojácich z povoláni: komentár̆. Praha: Wolters Kluwer, 2017, s. 35.

${ }^{100}$ Poznámka pod čarou však odkazuje na již zrušený branný zákon.

${ }^{101} \S 25$ odst. 1 zákona č. 585/2004 Sb., o branné povinnosti a jejím zajištování (branný zákon), ve znění pozdějších předpisů. 
ostatní funkce (člen Parlamentu, vlády, Veřejný ochránce práv, soudce, státní zástupce, prezident, viceprezident a člen Nejvyššího kontrolního úřadu, státní zaměstnanec) již neslučitelnost stanovena je, $\mathrm{z}$ hlediska legislativně-technického však nepříliš elegantně. Pro žádnou z funkcí není stanovena karenční doba, ${ }^{102}$ což potenciálně umožňuje, výše zmíněné, pouze formální dodržení požadavku neslučitelnosti funkcí.

Dalším problémem, potenciálně významnějším než formulace čl. 4 odst. 2 ÚZB, je nedostatečné vyjasnění kompetencí jednotlivých státních orgánů ve vztahu k obecnému vytyčení směru činnosti ozbrojených sil, a to zejména postavení prezidenta republiky jako vrchního velitele ozbrojených sil. ${ }^{103}$ Pochybné je též určení, komu by náleželo velení ozbrojeným silám v prŕípadě ozbrojeného konfliktu. ${ }^{104}$ Stěží najdeme jinou ústavně svěřenou kompetenci, jejíž obsah by byl tak nejistý, ${ }^{105}$ že umožňuje zástupcům doktríny vyslovovat tvrzení o jejím pouze ceremoniálním charakteru na straně jedné, ${ }^{106}$ na straně druhé však přisuzovat této kompetenci podstatný mocenský význam. ${ }^{107}$ Tuto nejednoznačnost nelze považovat za stav žádoucí, ba dokonce bezpečný. Existuje navzdory tomu, že byl z politologických pozic oprávněně kritizován jako nedostatek v zakotvení občanského vedení ozbrojených sil. ${ }^{108}$ Nezbývá než na tomto místě apelovat na právní doktrínu a normotvůrce, aby se část jejich pozornosti zaměřila právě na prezidentské kompetence $\mathrm{v}$ oblasti bezpečnosti státu; řešení potenciálních kompetenčních sporů v době př́ípadné bezpečnostní krize by pro náš stát bylo vskutku nešt’astné.

Co se týče stanovování účelů a preferencí, náleží vytváření obranné politiky v České republice vládě a v širším smyslu též Parlamentu. Ve druhé části článku jsme došli k závěru, že je nezbytné, aby parlamenty povinně zřizovaly zvláštní orgány pro záležitosti ozbrojených sil a obranné politiky. V českém právním řádu však není stanovena povinnost takový orgán zřídit, nebot’ ani zákon o jednacím řádu Poslanecké sněmovny, ani zákon o jednacím řádu Senátu nepředepisuje výbor pro obranu jako obligatorní orgán komory. ${ }^{109}$ Ke cti poslanců (i senátorů) slouží fakt, že takový výbor byl zatím vždy zřízen. Druhou nezbytností je vybavení Parlamentu personálem specializovaným výhradně na otázky týkající se ozbrojených sil a národní bezpečnosti, at' už v pomocném úřadu komory (Kancelář Poslanecké sněmovny, resp. Kancelář Senátu) nebo k tomu účelu zřizované samostatné instituci (à la branný zmocněnec německého Spolkového

\footnotetext{
102 Např. po vzoru $§ 12$ e odst. 3 zákona č. 152/1994 Sb., o zpravodajských službách České republiky, ve znění pozdějších předpisů (dále též ,ZZS”).

103 Čl. 63 odst. 1 písm. c) Ústavy.

104 Obé KŘÍŽ, Civilní řizení, s. 74-75.

105 Možná s výhradou čl. 63 odst. 1 písm. a) Ústavy. Za toto upozornění děkuje autor J. Kyselovi.

106 Srov. MOLEK, P. In: ŠIMÍČEK, V. a kol. Ústava České republiky: komentář. Praha: Linde, 2010, s. 761.

107 Srov. KOUDELKA, Z. Prezident republiky. 2., aktual. a dopl. vyd. Praha: Leges, 2018, s. 199 („,Obsahem vrchního veleni je určovat, že vojsko má být nasazeno...“) a s. 200-201 („Naše ústava nezabraňuje prezidentu republiky prímo ujmout se velení v poli.“). Koudelkův názor sice může být odmítnut jako názor v naší doktríně zcela marginální, nicméně je třeba upozornit na fakt, že právě tento silně proprezidentský výklad byl prezentován v odborném časopise Vojenské rozhledy (srov. KOUDELKA, Z. Prezident jako vrchní velitel. Vojenské rozhledy, 2012, roč. 21 (53), č. 1, s. 122-131), který je vojenskými odborníky a špičkami čten, a to na rozdíl od odborných publikací ústavněprávních. Na základě jakých zdrojů si tedy vojenští profesionálové budují své právní vědomí a představu o ústavním rozdělení kompetencí?

108 Srov. KřÍŽ, Civilní řizení, s. 74-75.

109 Srov. 332 zákona č. 90/1995 Sb., o jednacím řádu Poslanecké sněmovny, ve znění pozdějších předpisů, a $\$ 36$ odst. 1 zákona č. 107/1999 Sb., o jednacím řádu Senátu, ve znění pozdějších předpisů.
} 
sněmu). Tímto personálem Parlament nedisponuje, což vyvolává dohady o existenci významné informační asymetrie. Odstranění tohoto nedostatku je hlavním návrhem de lege ferenda $\mathrm{v}$ závěru této části.

\subsection{SOULAD NOREM A HODNOT SE STAVEM OSOBNÍHO SUBSTRÁTU V ČR}

Od dob první Československé republiky je u nás preferován spíše Huntingtonův subjektivní model občanského vedení. ${ }^{110}$ Tomu odpovídá i rozsah a intenzita výkonu dohledu nad stavem a činností ozbrojených sil. Ve druhé části jsme jako důležitou uvedli problematiku politických extremistů, atmosféru v ozbrojených silách s ohledem na porušování subjektivních práv vojáků a soulad činnosti ozbrojených sil s normami mezinárodního práva humanitárního a lidskoprávními závazky státu. Na tyto oblasti se zde zaměříme.

Co se týče politických extremistů, $v$ České republice se $\mathrm{k}$ této problematice upřel zrak veřejnosti v roce 2009 , kdy byly silně medializovány kauzy, při nichž armádní důstojníci na zahraniční misi v Afghánistánu nosili označení jednotek SS na svých přilbách ${ }^{111}$ či se profesionální vojáci podíleli na paramilitárním výcviku neonacistické organizace. ${ }^{112}$ Soudě podle výročních zpráv Vojenského zpravodajství113 a výročních zpráv Ministerstva vnitra o extremismu, ${ }^{114}$ je možné od roku 2004 identifikovat dvě, z extremistického hlediska nejfrekventovanější období.

První, probíhající v letech 2007-2010, je charakteristické objevením extremistů ve vojenských řadách, jakož i zaznamenáním pokusů extremistů se mezi př́slušníky ozbrojených sil dostat. Zprávy Ministerstva vnitra pak výrazně akcentují roli médií (zvláště MF Dnes) při odhalování prípadů extremismu v ozbrojených silách. V tomto období byl též zpracován výzkum M. Mareše, J. Smolíka a P. Vejvodové týkající se vztahu vojáků $\mathrm{k}$ politickému extremismu. ${ }^{115}$ Toto sociologické šetření kupř́íkladu odhalilo, že se $30 \%$ respondentů setkalo s politickým extremismem v rámci Armády ČR ${ }^{116}$ a více než polovina odpovídajících vojáků a vojákyň uvedla, že v rámci Armády je možné potkat extremisty či radikály. S projevy rasismu v Armádě se setkalo 43,5 $\%$ dotazovaných. ${ }^{117}$

\footnotetext{
110 Srov. Ǩ̌ÍŽ, Civilní řizení, s. 30-31.

111 Vyznamenaní velitelé z Afghánistánu nosili nacistické symboly. iDNES.cz [online]. [cit. 12. 11. 2019]. Dostupné z: https://www.idnes.cz/zpravy/domaci/vyznamenani-velitele-z-afghanistanu-nosili-nacisticke -symboly.A091108_231440_domaci_kot.

112 Armáda odstavila vojáky s SS symboly a vyhodila trenéra z White Justice. iDNES.cz [online]. [cit. 12. 11. 2019]. Dostupné z: https://www.idnes.cz/zpravy/domaci/armada-odstavila-vojaky-s-ss-symboly -a-vyhodila-trenera-z-white-justice.A091109_104459_domaci_cem.

113 Dostupné zde: https://www.vzcr.cz/vyrocni-zpravy-o-cinnosti-vojenskeho-zpravodajstvi-41.

114 Dostupné zde: https://www.mvcr.cz/clanek/extremismus-vyrocni-zpravy-o-extremismu-a-strategie-boje -proti-extremismu.aspx.

115 MAREŠ, M. - SMOLÍK, J. - VEJVODOVÁ, P. Extremismus z pohledu vojáků. Vojenské rozhledy, Brno: Ministerstvo obrany České republiky, Univerzita obrany v Brně, 2010, vol. 19 (51), č. 4.

116 MAREŠ - SMOLÍK - VEJVODOVÁ, c. d., s. 167.

117 MAREŠ - SMOLÍK - VEJVODOVÁ, c. d., s. 169.
} 
Po tomto období je možné několik let mluvit o útlumu extremistických aktivit v rámci ozbrojených sil,118 které však opět rostou mezi lety 2013-2016. Toto období je spojeno nejprve s trestní kauzou nedovoleného ozbrojování př́slušníka ozbrojených sil, který byl označen za člena „tvrdého jádra” tzv. pravicového extremismu, dále pak kontakty extremistických vojáků s hnutím hooligans, a s tím spojeným nárůstem násilí, neonacistickou symbolikou, ${ }^{119}$ konspirativním jednáním jednotlivců či projevy rasismu na sociálních sítích. Novinku tvoří též fenomén paramilitarismu. Také v tomto období byl zpracován (interní) průzkum v rámci Armády, který přinesl zjiššění, že ,zhruba polovina vojáku by podpořila takovou politickou stranu, která by nabídla radikální řešení romské otázky, a asi pět procent vojáki̊ se účastní extremistických demonstraci" ${ }^{120}$ Obě vrcholná období, zdá se, souvisí i s vrcholy napětí mezi romskou minoritou a zbytkem společnosti v ČR, at’ už jde o události v Janově roku 2007, kauzu vítkovských žhářŭ v roce 2009 nebo události v Duchcově a Českých Budějovicích v roce 2013.121

Přestože podle opakovaných ujištění ze strany jak vládních a vojenských představitelů, tak i Vojenského zpravodajství a Ministerstva vnitra nejde v našich ozbrojených silách o masový jev, není radno riziko extremismu, soudě podle sociologických zjištění, podceňovat. Pro oblast ústavního práva je zajímavé si povšimnout, že problematika extremismu v ozbrojených silách byla řešena pouze $\mathrm{v}$ rámci výkonné moci, resp. uvnitř ozbrojených sil. Občanské vedení zde tak zastupovalo pouze vedení Ministerstva obrany, bez účasti Parlamentu či jiných mimoexekutivních orgánů; nedošlo ani k systémovým opatřením prohlubujícím parlamentní dohled nad činností ozbrojených sil, ani k podání písemných interpelací či ke zřízení vyšetřovací komise ve věci extremismu v ozbrojených silách. Vnější, mimoexekutivní občanské vedení tak zde reprezentovali neinstitucionální aktéri, zejména média a členové akademické sféry. ${ }^{122}$

Druhou oblastí je sledování atmosféry uvnitř ozbrojených sil v souvislosti s ochranou lidských práv a svobod vojáků, což je téma řešené v naší společnosti zejména po Listopadu 1989. ${ }^{123}$ Systém ochrany lidských práv v rámci ozbrojených sil lze označit za solidní; v rámci resortu Ministerstva obrany existuje odbor inspekce ministra obrany, jehož součástí je i pozice hlavního inspektora ochrany lidských práv. ${ }^{124}$ Taktéž Základní řád ozbrojených sil upravuje vnitřní stížnostní mechanismus na porušováním práv vojákủ, ${ }^{125}$ kterým nesmí být stížnost na újmu, ve výkonu práva na podání stížnosti nesmí být

118 Zprávy z tohoto „mezidobí“ hovoří o přesunu aktivit extremistů mimo vojenské struktury. Ministerstvo vnitra však i zde poukazuje na objevující se rasistické urážky, nacistická tetování vojákủ či udržování kontaktů s extremistickými skupinami.

119 Opět tetování či nacistický pozdrav Sieg Heil.

${ }^{120}$ Vojáci podporují extremisty, v armádě je korupce. Špatná vizitka, říká o průzkumu Babiš. Hospodářské noviny (IHNED.cz). [online]. [cit. 12. 11. 2019]. Dostupné z: https://domaci.ihned.cz/c1-64663210-vojaci -podporuji-extremisty-v-armade-je-korupce-spatna-vizitka-rika-o-pruzkumu-babis.

${ }^{121}$ Srov. MAREŠ, M. - VÝBORNÝ, Š. Militantní demokracie ve střední Evropě. Brno: Centrum pro studium demokracie a kultury (CDK), 2013, s. 119.

122 Jejich roli akcentuje např. STACH - SARVAŠ, c. d, s. 44, či obecně jako součást vyspělé politické kultury VLACHOVÁ, c. d., s. 203.

123 Vzpomeňme jen na knihy a filmy s touto tematikou, které zachycovaly prostředí ozbrojených sil v době komunistické totalitní moci, jako je Tankový prapor, Černí baroni či méně známý film Zobani (1993).

${ }^{124}$ Srov. Odbor inspekce ministra. Ministerstvo obrany. [online]. [cit. 12. 11. 2019]. Dostupné z: http://www .mocr.army.cz/ministr-a-ministerstvo/sdk/odbor-inspekce-ministryne-105920/.

125 Čl. 9 a násl. Zákl-1. 
vojákovi bráněno a je zakázáno jej vystavovat nátlaku, aby svou stížnost odvolal. ${ }^{126} \mathrm{Bez}$ možnosti obrátit se se svou stížností na orgány mimo vnitřní strukturu velení by však tyto záruky byly pouze iluzorní; z tohoto důvodu mohou stížnosti vyřizovat i specializované orgány vnitřního dohledu (např. odbor inspekce ministra), ${ }^{127}$ přičemž pokud jde o závažná porušení lidských práv, je možné se obrátit přímo na již zmíněného (civilního) hlavního inspektora ochrany lidských práv. ${ }^{128}$ Inspekční orgán je zř́zen i v rámci Generálního štábu Armády ČR, jehož vedoucí má zároveň postavení zástupce náčelníka Generálního štábu. ${ }^{129}$

Pro vnější dohled existuje na základě zákona č. 349/1999 Sb. Veřejný ochránce práv, do jehož působnosti ochrana základních práv a svobod plně spadá. Působnost veřejného ochránce však není stanovena plošně na ozbrojené síly, ale pouze na Armádu ČR a Hradní stráž. ${ }^{130}$ Nepostihuje tak všechny útvary, v nichž působí vojáci v činné službě. Jakkoliv je výluka Vojenského zpravodajství odůvodněna jeho charakterem zpravodajské služby, není důvodné, proč se působnost Veřejného ochránce práv nevztahuje na Vojenskou policii, ${ }^{131}$ př́padně též na Vojenskou kancelář prezidenta republiky, Generální štáb Armády ČR nebo na vojenské školy. ${ }^{132}$ Vyloučení části ozbrojených sil (ve smyslu uvedeném v první části) z dosahu vedoucích (resp. dohlížecích) orgánů znefunkčňuje občanské vedení; ${ }^{133}$ také z tohoto důvodu je nutné trvat na shora uvedené (mezinárodněprávní, ústavní a vojensko-teoretické) definici ozbrojených sil.

Třetí oblastí je soulad činnosti ozbrojených sil s mezinárodním humanitárním právem a lidskoprávními závazky státu. Ačkoliv ve střední Evropě nedošlo již více než 70 let k ozbrojenému konfliktu, účastní se naše ozbrojené síly dlouhodobě bojových akcí, při nichž reálně válčí. Tím jsou myšleny zahraniční mise, at' už v rámci Organizace spojených národů, ${ }^{134}$ Evropské unie, ${ }^{135}$ Organizace Severoatlantické smlouvy, ${ }^{136}$ nebo mimo tyto mezinárodní organizace. ${ }^{137} \mathrm{~V}$ ř́ijnu 2018 došlo právě v rámci zahraniční mise našich ozbrojených sil v Afghánistánu k události, jejiž řešení je dle mínění autora tohoto článku jedním z nejvýznamnějších selhání občanského vedení ozbrojených sil u nás.

126 Čl. 13 Zákl-1.

127 Čl. 15 Zákl-1.

128 Čl. 18 Zákl-1.

129 Srov. Inspektorát NGŠ. Armáda ČR. [online]. [cit. 12. 11. 2019]. Dostupné z: http://www.acr.army.cz /struktura/generalni-stab/inspektorat-ngs-42915/.

130 Srov. $\$ 1$ odst. 2 zákona č. 349/1999 Sb., o Veřejném ochránci práv, ve znění pozdějších předpisů.

131 Zvlášt', když se na Policii ČR, mimo činnost, kterou vykonává jako orgán činný v trestním řízení, vztahuje. Vojenská policie navíc nepůsobí pouze ve vztahu k vojákům, nýbrž i ve vztahu k civilistům (§ 1, § 3 písm. b), c) zákona č. 300/2013 Sb., o Vojenské policii, ve znění pozdějších předpisů, dále též ,ZvojPol“"), přičemž vojenští policisté jsou oprávněni používat donucovací prostředky nebo zbraně v obdobném rozsahu jako policisté Policie ČR (srov. § 45-46 ZVojPol).

132 Ani Vojenská kancelář prezidenta republiky, ani Generální štáb Armády ČR není ve smyslu $§ 3$ odst. 2 a $\$ 7$ odst. 3 ZOS součástí Armády ČR. U vojenských škol byla tato otázka řešena Nejvyšším správním soudem (čj. 9 As 16/2008 - 84) extenzivním výkladem tak, že je na ně třeba pohlížet jako na součást Armády ČR, byt' to z právních předpisů př́iliš nevyplývá.

133 VLACHOVÁ, c. d., s. 201.

134 Zejména mise UNPROFOR, IFOR a SFOR v bývalé Jugoslávii.

135 Zejména mise EU TM v Mali.

136 Zejména mise ISAF a operace Rozhodná podpora (Resolute Support) v Afghánistánu.

137 Zejména operace Trvalá svoboda (Enduring Freedom) v Afghánistánu. 
O co v této kauze jde? ${ }^{138}$ Po sérii útoků na naše vojáky v Afghánistánu, při nichž jich několik zemřelo, byl zadržen příslušník afghánské armády V. Chán, který byl považován za jednoho z útočníků. Podle dostupných zpráv se ke svému činu i doznal a byl předán nejprve českým a posléze i americkým vojákům k provedení tzv. taktického výslechu. O provedení taktického výslechu českým vojenským personálem údajně neexistuje jinak obligatorní písemný záznam, též výpovědi svědků se liší. Po skončení amerického taktického výslechu byl předán opět českým vojákům ke střežení do doby, než bude odevzdán afghánským úřadům. Podle afghánských úřadů, jejichž líčení událostí se liší od českých svědectví, již V. Chán nebyl schopen chodit a nedlouho po jeho převzetí musel být převezen do nemocnice, kde podle lékařské zprávy zemřel v důsledku mnohačetných zranění.

V listopadu 2018 vyšel v americkém The New York Times článek, který naznačil, že V. Chán se stal obětí mučení ze strany spojeneckých vojenských sil, přičemž poukázal na vyšetřování, které bezprostředně po událostech provedlo americké Army Criminal Investigations Divisions (CID). Toto vyšetřování, zahrnující i užití forenzních metod, údajně nalezlo ve vyšetřovací místnosti veliký počet krevních stop V. Chána, mj. na stěně či stropu místnosti. V reakci na tento článek jak předseda vlády, tak i ministr obrany a náčelník Generálního štábu Armády ČR striktně odmítli jakoukoliv účast českých vojáků na špatném zacházení s V. Chánem, v jehož důsledku měl zemřít. ${ }^{139} \mathrm{~V}$ průběhu října nebo listopadu 2018 proběhlo dle J. Spurného též vyšetřování komise Generálního štábu, které však bylo podle něj vedeno zcela povrchně. J. Spurný též zmiňuje, že došlo k intenzivní komunikaci mezi českým armádním velením a afghánskými úřady, a to prý s cílem zakrýt některé informace.

Američtí vyšetřovatelé po dokončení vyšetřování měli neoficiálně předat zprávu o jeho výsledcích zástupcům Vojenské policie, která pod dozorem státního zástupce zahájila úkony trestního řízení v květnu 2019, tj. po téměř 7 měsících od incidentu. V červnu 2019 došlo opět k medializaci kauzy, a to v souvislosti se zasláním diplomatické nóty afghánské vlády vládě ČR týkající se právě případu V. Chána. ${ }^{140}$ V červenci 2019 došlo k zásahu Vojenské policie na Generálním štábu Armády ČR a v sídle 601. skupiny speciálních sil generála Moravce v Prostějově. ${ }^{141}$ Podle tiskového sdělení Městského státního

${ }^{138}$ Následující rekonstrukce událostí vychází z rozhovoru redaktora časopisu Respekt J. Spurného, který poskytl Českému rozhlasu. Tento rozhovor je dostupný zde: https://www.irozhlas.cz/zpravy-domov /spurny-afghanistan-respekt-podcast-vinohradska-12_1908150600_bar. Přehled podává též článek K. Guryčové (Případ zbitého afghánského vojáka: české úřady jeho smrt začaly vyšetřovat až po 207 dnech. iROZHLAS - spolehlivé zprávy. [online]. [cit. 12. 11. 2019]. Dostupné z: https://www.irozhlas .cz/zpravy-domov/cesti-vojaci-afghanistan-specialni-jednotky-smrt-vojaka-biti_1908040600_kno). Vzhledem k povaze věci není možné vycházet v současné době z jiných informací než z těch, které byly zveřejněny v médiích.

139 Vyjádření ministra obrany a náčelníka Generálního štábu Armády ČR je dostupné např. zde: https:// www.irozhlas.cz/zpravy-domov/metnar-opata-afghanistan-cesti-vojaci_1811281451_miz.

140 Diplomatická nóta kvůli smrti českých vojáků. Afghánské úřady se obrátily na ministerstvo zahraničí. iROZHLAS - spolehlivé zprávy. [online]. [cit. 12. 11 2019]. Dostupné z: https://www.irozhlas.cz /zpravy-domov/diplomaticka-nota-afghanistan-smrt-ceskych-vojaku-ministerstvo-zemedelstvi 1907110600_kno.

141 ,Prověřují úmrtí afghánského vojáka. Vojenská policie zasahovala na generálním štábu a v Prostějově. iROZHLAS - spolehlivé zprávy [online]. [cit. 12. 11 2019]. Dostupné z: https://www.irozhlas.cz/zpravy -domov/vojenska-policie-generalni-stab-prostejov_1907241549_pj. 
zastupitelství v Praze bylo v souvislosti s touto kauzou zahájeno trestní stíhání 4 osob pro trestný čin neoznámení trestného činu, ${ }^{142}$ který se ve smyslu $§ 368$ odst. 1 trestního zákoníku vztahuje mj. na trestný čin vraždy, těžkého ubližení na zdraví, mučení a jiného nelidského a krutého zacházení nebo válečné krutosti. Toto trestní stíhání bylo po čtyřech měsících zastaveno a věc se vrátila do stádia prověřování. ${ }^{143}$

Není úkolem tohoto článku vyvozovat trestní či jinou právní odpovědnost kohokoliv nebo přinést dosud neznámé informace, které se týkají kauzy úmrtí V. Chána (tyto ostatně podléhají v naprosté většině utajení). At’ už se naši vojáci zúčastnili mučení V. Chána, nebo ne, je dosud známý průběh této kauzy, jakož i informace o začátku a průběhu šetření, z hlediska občanského vedení velice znepokojivý.

Vyplývá-li, dle současného stavu judikatury, z pozitivního závazku na účinné vyšetřování v př́ípadech možného porušení práva na život a práva nebýt mučen ${ }^{144}$ požadavek efektivního a rychlého vyšetřování, nelze za ně označit prodlení téměř 7 měsíců, ${ }^{145}$ během kterých došlo pouze $\mathrm{k}$ vyšetření zřejmě bez běžných vyšetřovacích úkonů, ${ }^{146}$ a to orgánem (zde komise Generálního štábu), který nesplňuje požadavek nezávislosti a nestrannosti. Navíc, v takových př́padech nelze zajistit běžnými nástroji úplný veřejný dohled nad vyšetřováním. ${ }^{147}$ Důvodem je jednak režim utajení, jednak již zmíněná specifická povaha vojenské organizovanosti - projevuje se tu totiž zvlášt’ silná „vnitřní soudržnost ozbrojených sil a vojenských profesionálů mezi sebou v nich“, 148 o které se ostatně zmiňuje i J. Spurný. O to více je třeba existence institucionalizovaných a specializovaných dohlížecích orgánů. ${ }^{149}$

Navíc, pokud se potvrdí, že vysocí vládní a armádní představitelé, odmítající obvinění ze strany The New York Times, se v inkriminované době bud' snažili aktivně zamést stopy, nebo byli záměrně udržováni v nevědomosti, pak lze označit vnitřní, exekutivní

142 Městské státní zastupitelství v Praze - Tiskové sdělení ze dne 25. 7. 2019. [online]. [cit. 12.112019 ]. Dostupné z: http://portal.justice.cz/Justice2/soud/soud.aspx?o=25\&j=35\&k=5960\&d=363238.

${ }^{143}$ Státní zástupce zastavil stíhání čtyř Čechů v př́ípadu smrti afghánského vojáka. Kauzu vrátil policii. iROZHLAS - spolehlivé zprávy [online]. [cit. 28. 12. 2019]. Dostupné z: https://www.irozhlas .cz/zpravy-domov/tomas-prochazka-vysetrovani-ceska-armada-trestni-stihani-afghanistan-ales-opata 1911282146_gak.

144 Je nanejvýs sporné, zda se na tento konkrétní př́ípad vzhledem ke známým skutkovým okolnostem vztahují normy mezinárodního humanitárního práva (spíše ne), proto je v dalším výkladu pracováno pouze s lidskoprávními závazky republiky.

${ }^{145}$ Evropský soud pro lidská práva posoudil prodlení 10 měsíců od úmrtí osoby v detenci za neslučitelné se závazky plynoucími z Úmluvy. Srov. MOLEK, c. d., s. 61. Rozdíl 3 měsíců nepředstavuje dle autora článku natolik zásadní odchylku, která by byla již s lidskoprávními závazky státu souladná. Pokud by bylo toto prodlení shledáno za souladné s našimi závazky vyplývajícími z Úmluvy, pak bychom s touto dobou de lege ferenda neměli býti spokojeni, máme-li míti stát založený na úctě k právům a svobodám člověka a občana (čl. 1 odst. 1 Ústavy).

${ }^{146}$ Evropský soud pro lidská práva za takové úkony považuje výslechy svědků, ohledání místa činu a osob včetně specializovanějších kriminalistických metod. Srov. KRATOCHVÍl In: KMEC a kol., c. d., s. 372.

${ }^{147}$ Tím je např. př́stup do spisu. Srov. MOLEK, c. d., s. 62-63.

148 ČERNOCH, F. Některé aspekty profesionalizace ozbrojených sil. In: PAVLÍČEK, V. a kol. Právo a bezpečnost státu: sborník statí. Praha: Univerzita Karlova v Praze, Právnická fakulta v nakl. Vodnář, 2002, s. 172.

${ }^{149}$ Nejpř́ísnější režim utajení je zachováván při činnosti zpravodajských služeb. Právě proto zákonodárce přistoupil k zavedení dvouúrovňového systému kontroly (ve smyslu dohledu); na první úrovni kontrolu vykonávají stálé komise Poslanecké sněmovny, ve druhé úrovni pak specializovaný Orgán nezávislé kontroly zpravodajských služeb. Viz § 12 a §12e a násl. ZZS. 
občanské vedení ozbrojených sil za nedostatečné. Je-li též pravda, že státní zastupitelství nemůže získat přístup $\mathrm{k}$ výše zmíněné komunikaci mezi armádním velením a afghánskými úřady, pak se, spolu se sedmiměsičním prodlením mezi úmrtím a zahájením trestního ř́zení, nabízí otázka, zda je stávající nastavení veřejné žaloby ve specifických podmínkách ozbrojených sil a vojenských konfliktů dostatečně specializované.

\subsection{SOULAD ÚČELŮ A PREFERENCÍ SE STAVEM VĚCNÉHO SUBSTRÁTU V ČR}

S materiální složkou ozbrojených sil jsou spojeny nejznámější kontroverze, týkající se občanského vedení ozbrojených sil, a sice velké zbrojní zakázky. Právě otázku efektivity využivání materiálních a peněžních zdrojů na zajištění úkolů ozbrojených sil považuje Z. Kř́iž za hlavní nedostatek v realizaci občanského vedení u nás. ${ }^{150}$

Naši političtí představitelé se $\mathrm{k}$ významnějšímu navyšování vojenských rozpočtů staví, přes všechnu podporující rétoriku, dlouhodobě spiše rezervovaně, ${ }^{151}$ dost možná proto, že výdaje na obranu nejsou u veřejnosti př́iliš populární (a to i když ozbrojené síly patří dlouhodobě k nejdůvěryhodnějším veřejným institucím). ${ }^{152}$ Pokud ale již dojde $\mathrm{k}$ realizaci vyzbrojovacího projektu, je tento často veřejností označen nálepkou korupční kauzy. ${ }^{153}$ Možné zlepšení výkonu občanského vedení však neleží v oboru práva ústavního, ale v jiných právních oborech (trestní právo, správní právo a veřejné zakázky), proto tuto problematiku opustíme. Nicméně ústavní relevanci má jistě dohledová činnost Nejvyššího kontrolního úřadu, jakož i činnost Parlamentu.

Kompetence Nejvyššího kontrolního úřadu stanovená Ústavou a prováděcím zákonem oblast ozbrojených sil a jejich činnosti zahrnuje, a sám Nejvyšší kontrolní úřad ji i několikrát využil, at' už s obecným záměrem či se zaměřením na obrněnou, automobilní nebo leteckou techniku. ${ }^{154}$ Co se týče Parlamentu, není v současné době pozitivněprávně zakotvena účast na zbrojních zakázkách, resp. na jejich schvalování; je tedy nutné spoléhat se na politickou kulturu, což ovšem nemusí být nutně chybou, protože, jak bylo uvedeno v části druhé, i v Německu jde při schvalování zbrojních zakázek pouze o politickou praxi.

150 Srov. KŘÍŽ, Civilní řizení, s. 102.

151 To v roce 2004 pro další léta predikoval i Z. Kříž (srov. KříŽ , Civilní řizení, s. 63), a to i bez znalosti o roku 2008 vypuknuvší finanční krizi a s ní souvisejícím krácením armádních výdajů. Ani po skončení této krize a postupným navyšováním rozpočtové kapitoly Ministerstva obrany v souvislosti s nepříznivým bezpečnostním prostředím se výdaje na ozbrojené síly nepřibližují často skloňovaným 2 \% HDP, které náš stát vynakládal naposledy v roce 2005 (tedy v době, kdy Z. Kříž svou studii psal) - srov. Resortní rozpočet. Ministerstvo obrany. [online]. [cit. 14. 11. 2019]. Dostupné z: http://www.mocr.army .cz/finance-a-zakazky/resortni-rozpocet/resortni-rozpocet-5146/.

152 Srov. Tisková zpráva. Důvěra k vybraným institucím veřejného života - září 2019. [online]. [cit. 14. 11. 2019]. Dostupné z: https://cvvm.soc.cas.cz/media/com_form 2 content/documents/c2/a5011/f9 /po191008.pdf. Avšak i nechut' české veřejnosti k armádním výdajům se možná mění, jak o tom referoval výzkum CVVM z kraje roku (srov. Důvěra v armádu u lidí roste. Věří, že náklady na obranu nejsou zbytečné. iDNES.cz. [online]. [cit. 14. 11. 2019]. Dostupné z: https://www.idnes.cz/zpravy/domaci/obrana -armada-cr-cvvm-pruzkum-verejne-mineni.A190208_160331_domaci_rko).

153 Vzpomeňme třeba na kauzu spojenou s nákupem letāel Gripen a CASA či obrněných vozidel Iveco, Dingo a Pandur.

${ }^{154}$ Viz Vyhledávač kontrol. NKÚ. [online]. [cit. 14. 11. 2019]. Dostupné z: https://www.nku.cz/scripts $/$ rka/prehled-kontrol.asp?nazevakce $=\&$ casovyfiltr $=0 \&$ kategorie $=15 \&$ trestnioznameni $=0 \&$ oznamenifu $=0 \&$ hledat $2=$ hledat $\&$ rozsirene $=1 \&$ odeslano $=1$. 
V tomto článku bylo na několika místech poukázáno na nedostatečnou implementaci občanského vedení ozbrojených sil u nás. Jde jednak o nezakotvení občanského vedení jako obecného ústavního principu, opomenutí prezidenta republiky ve výčtu veřejných funkcí neslučitelných s výkonem vojenské činné služby nebo nejednoznačné vymezení kompetencí při řízení ozbrojených sil s ohledem na postavení prezidenta republiky jako vrchního velitele ozbrojených sil, jednak o problematickou definici ozbrojených sil v zákoně o ozbrojených silách ČR či o nedostatečnou působnost Veřejného ochránce práv ve vztahu k ozbrojeným silám. Všechny tyto nedostatky není $\mathrm{z}$ teoretického hlediska př́liš obtížné zhojit, byt' $\mathrm{v}$ jednom až dvou případech vyžadují přijetí ústavní novely a zvýšenou pozornost naší ústavněprávní nauky.

Podstatnější mezerou je nedostatečný vhled Parlamentu do záležitostí ozbrojených sil z důvodu absence alternativních, na exekutivě nezávislých, avšak odborných informací. Tento zásadní nedostatek významně znesnadňuje výkon parlamentní kontrolní funkce (resp. funkce občansko-vedoucí), at' už ve smyslu spolurozhodování v branných záležitostech (stanovení institucionálního jádra) nebo dohlížecí činnosti nad ozbrojenými silami (sledování a hodnocení souladu institucionálního jádra se stavem osobní a věcné složky). Taktéž nenapomáhá $\mathrm{k}$ co možná nejvyšší realizaci závazků, které pro naši republiku vyplývají z mezinárodního práva ve smyslu čl. 1 odst. 2 a čl. 10 Ústavy, jakož i povinnosti veřejné moci respektovat, chránit a naplňovat základní práva a svobody osob.

Ke zmírnění tohoto nedostatku by mohlo sloužit vytvoření nového odborného orgánu, nezávislého na výkonné moci, specializovaného na oblast ozbrojených sil, a to po vzoru německého branného zmocněnce. Takový orgán navíc není znám pouze z německé právní úpravy, ale znají jej též v Dánsku, 155 Švédsku, Norsku, Irsku, Kanadě, Austrálii a Izraeli a v jistém smyslu i v Nizozemsku. ${ }^{156}$ Při jeho zř́zení je též možné využít i našich, byt' spíše formálních, zkušeností, nebot' takový orgán byl v podmínkách československé federace zaveden dosud výslovně nederogovaným zákonem č. 540/1990 Sb., o Generálním inspektorovi ozbrojených sil České a Slovenské Federativní Republiky. Tento první orgán ombudsmanského typu u nás, který nebyl pro politické neshody nikdy obsazen, může zejména vymezením působnosti a oprávněními sloužit jako výchozí podklad pro naše zákonodárné snažení. Působnost a oprávnění generálního inspektora se nakonec př́liš nelišily od svého inspiračního modelu (německého branného zmocněnce), nebot’ stejně jako v Německu obsahovaly v § 2-3 a § 5-7 oprávnění vyžadovat zprávy od zodpovědných členů vlády a vojenských funkcionár̆ů, konat neohlášené inspekce, rozmlouvat s vojáky a prostřednictvím zpráv o mimořádných událostech i o jejich disciplinárních a jiných deliktech nebo povinnost pravidelně informovat zákonodárný sbor; absentovalo pouze oprávnění vstupovat jako zvláštní procesní subjekt do

155 Srov. čl. 55 dánské ústavy.

156 Srov. EUROPEAN COMMISSION FOR DEMOCRACY THROUGH LAW (VENICE COMMISSION), c. d., s. $65-67$. 
rízení týkajících se ozbrojených sil a jejich př́slušníků, a nárok na tzv. úřední pomoc od všech orgánů veřejné moci. ${ }^{157}$

Vzhledem k existenci Veřejného ochránce práv by, při současném rozšíření jeho působnosti, do působnosti tohoto zvláštního kontrolního orgánu nemusela být svěřena ochrana základních práv a svobod uvnitř ozbrojených sil. ${ }^{158}$ Co by však bylo třeba vyřešit, je otázka kreace a funkčního období tohoto orgánu. Pokud by měl sloužit výhradně jako pomocný orgán Parlamentu, dávalo by jistý smysl převzít i v tomto směru federální právní úpravu. Pokud by však měla být zdůrazněna jeho role jako orgánu odborného, stálo by za úvahu stanovit podmínky pro výkon funkce a delší funkční období s omezenou možností jej z funkce odvolat. Pro samotný mechanismus kreace se nabízí model Veřejného ochránce práv.

\title{
5. ZÁVĚR
}

Dělba moci ve státě, vzájemně provázaný systém kontroly orgánů veřejné moci, ochrana základních práv a svobod prostřednictvím institucionálních záruk - to vše jistě není zadarmo. Jinak tomu není ani v př́ipadě občanského vedení ozbrojených sil v době, kdy se riziko vojenských převratů všeobecně považuje za minimální, zejména pokud se pro jeho prohloubení zřizují specializované struktury a instituce. Tento článek měl kromě vymezení pojmu ozbrojených sil, teoretického představení fenoménu občanského vedení z ústavněprávního hlediska, poukázání na vybrané nedostatky v normativně-institucionálním zakotvení tohoto fenoménu a návrhů de constitutione et lege ferenda za úkol též přesvědčit čtenáře, že je třeba se o brannou problematiku více zajímat i z ústavněprávního úhlu pohledu, a že vynaložené náklady na zajištění občanského vedení mohou být přinejmenším vyváženy př́nosy. Zda se to povedlo, necht' posoudí čtenáŕ sám.

\author{
Mgr. Jakub Dienstbier \\ Právnická fakulta Univerzity Karlovy \\ j.dienstbier@seznam.cz
}

\footnotetext{
157 Srov. UNGER, S. In: MANGOLDT, H. von - KLEIN, F. - STARCK, Ch. - HUBER, P. M. - VOßKUHLE, A. Grundgesetz: Kommentar. 7. Auflage. München: C. H. Beck, 2018, s. 1283-1284.

158 Pokud by se o porušování dozvěděl, mohl by tuto věc postoupit Veřejnému ochránci práv či o tom rovnou informovat Parlament, resp. příslušné orgány komor. Pokud by se dozvěděl o možném spáchání trestném činu, mohl by informovat nejvyššího státního zástupce po vzoru Orgánu nezávislé kontroly zpravodajských služeb.
} 